DE91 002582

SAND90-7098

Distribution

Unlimited Release

Printed October 1990

Category UC-630

\title{
Revision of Species Inventory Checklists for Sandia National Laboratories, Albuquerque Bernalillo County, New Mexico
}

Final Report

\author{
N. Timothy Fischer \\ International Technology Corporation \\ 5301 Central Avenue, NE, Suite 700 \\ Albuquerque, NM 87108 \\ Task Leader: Theodore A. Wolff
}

Sandia Contract 23-5505A

\begin{abstract}
This report revises and updates the 1974 report by W. C. Martin and W. L. Wagner, Biological Survey of Kirtland Air Force Base (East). The biological communities of Kirtland Air Force Base (KAFB) are described with respect to the Biome classification system of Brown (1982), and a standardized system of habitat types is proposed based on biome and soil type. The potenticl occurrence of State or Federally endangered species is discussed. No species listed as endangered or threatened is known to cccur on KAFB, although five are identified as potentially occurring. Updated lists of amphibians, reptiles, breeding birds, mamals, and plants are presented.
\end{abstract}

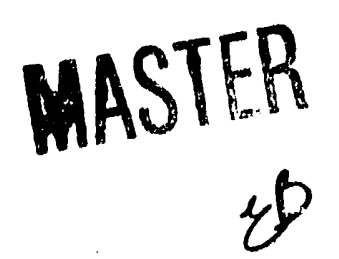




\section{TABLE OF CONTENTS}

PAGE

LIST OF TABLES..................................................................................................... it

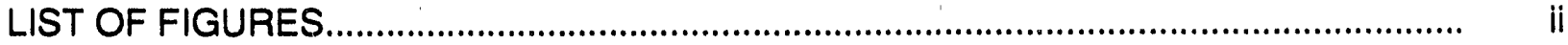

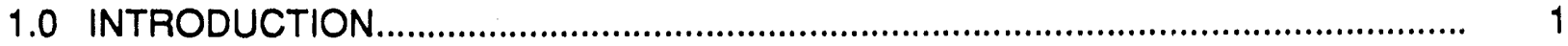

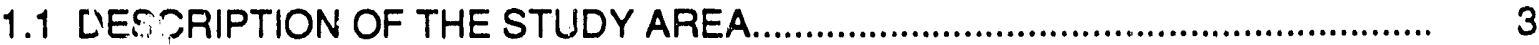

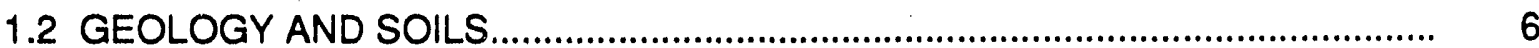

1.3 BIOLOGICAL COMMUNITY CLASSIFICATION ............................................. 8

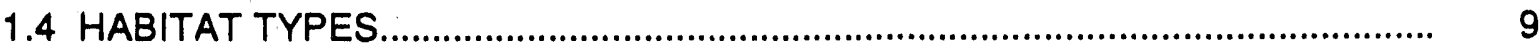

1.5 PROTECTED SPECIES AND SENSITIVE HAEITATS.................................... 10

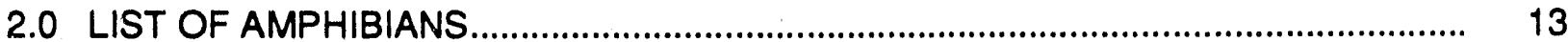

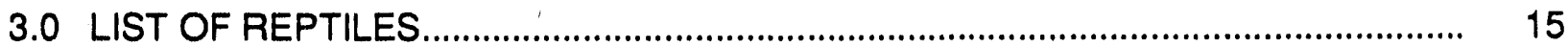

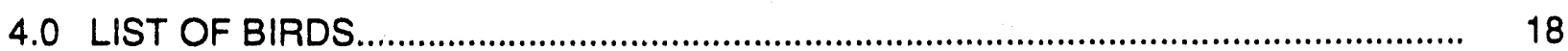

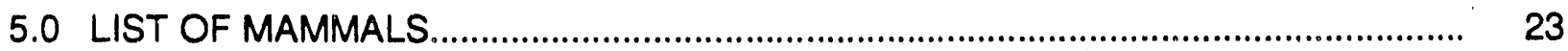

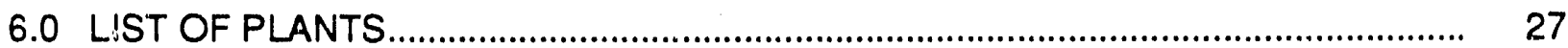

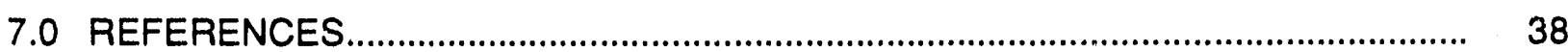




\section{LIST OF TABLES}

TABLE NO.

TITLE

2.1

2.2

3.1

3.2

4.1

5.1

5.2

6.1
List of Amphibians With a Moderate to High Probability of Occurrence on KAFB

List of Amphibiarıs With a Low Probability of Occurrence on KAFB

List of Reptiles With a Moderate to High Probability of Occurrence on $\mathrm{KAFB}$

List of Reptiles With a Low Probability of Occurrence on KAFB

List of Potential Breeding Birds for KAFB

List of Mammals With a Moderate to High Probability of Occurrence on KAFB

List of Marrmals With a Low Probability of Occurrence on KAFB

List of Plants With a Moderate to High Probability of Occurrence on KAFB

\section{LIST OF FIGLRES}

FIGURE NO.

1.1

\section{TITLE}

Kirtland Air Force Base and Sandia National Laboratories, Albuquerque

Drainage Pattern and Springs on Kirtland Air Force Base

Soil Map of Kirtland Air Force Base 


\subsection{INTRODUCTION}

In response to a growing need for baseline information on the biological environment contained within Kirtland Air Force Base (KAFB), Sandia National Laboratories, Albuquerque (SNLA) contracted researchers from the University of New Mexico in the early 1970s to perform a biological survey of the base and prepare species lists of the higher plants and animals likely to occur within its boundary. In addition to the annotated checklists of amphibians, reptiles, birds, mammals, and plarits, the resulting report (Martin and Wagner, 1974) provides descriptions of the general physical environment (topography, geology, soils, and climate) on KAFB and a detailed discussion of the floristic affinities of the major plant communities observed during the fielc surveys. The animal lists in this report are primarily based on literature review. Only the plant list was corroborated by field collections.

Since its release, the biological survey report of Martin and Wagner has been used as the primary source document for descriptions of the biological environment in several subsequent documents, including the Sandia Laboratories Environmental Impact Assessment (Sandia National Laboratories, 1977) and the Strategic Defenses Facility environmental assessment (Department of Energy, 1988). For its time, the biological survey of Martin and Wagner was excellent and thorough. However, since that work was completed, new information has become available which has necessitated its revision.

The most pervasive changes affecting the species lists are changes in accepted taxonomy and nomenclature. Taxonomic change is a continuing process in biology and periodic update of active species lists should be performed. All of the lists in ine original report, with the exception of the mammals, required at least some changes in names or taxonomic order. The taxonomic ordering of passerine birds, in particular, has undergone significant changes by the American Ornithologists' Union with the joining of the wood warblers, sparrows, and icterids into one large family, the Emberizidae.

A second area of change over the past fifteen years has been the availability of reference material. Significant references published since 1974 include: The Cacti of the United States and Canada (Benson, 1982), A Handbook of Rare and Endemic Plants of New Mexico (New Mexico Native Plants Protection Advisory Committee, 1984), Soil Survey of Bernalillo County 
and Parts of Sandoval and Valencia Counties, New Mexico (Hacker, 1977), and Biotic Communities of the American Southwest - United States and Mexico (Brown, 1982). Two references now published, A Flora of New Mexico (Martin and Hutchins, 1980) and Mammals of New Mexico (Findley et al., 1975) were cited as manuscripts in the original report. The Check-List of the Birds of New Mexico (Hubbard, 1970), cited in the original report, has since been revised and republished (Hubbard, 1978).

Although the primary goal of this report is to update the species lists in the original checklists of Martin and Wagner in accordance with recent changes in accepted taxonomy, other changes have also been made. Based on the current literature, the occurrence of some species, such as the black-tailed prairie dog and pronghorn antelope, is highly improbable on KAFB and these were removed from lists to avoid possible misrepresentation in future reports. Species which were not listed but which appear now to have a higher probability of being present than perhaps originally thought were added to the lists. Information is also provided on the listed threatened and endangered species based on consultation with regulatory agencies and selected references [New Mexico Department of Game and Fish (no date); New Mexico Native Plants Protection Advisory Committee, 1984].

For the amphibians, reptiles, and mammals, a list of species which have a low probability of occurring on KAFB is provided separately from the list of species having a moderate or high probability of occurrence. These are typically species for which the location and habitat conditions of the site are marginal. Until field surveys verify their presence, these lowprobability species should not be cited as being present.

Another significant change from the original checklists is the removal of migrant birds. Bird migration presents a difficult problem to the development of a meaningful species inventory. If migrants are to be included, decisions must be made, which are usually highly subjective, as to which are common and which constitute casual or accidental occurrences. The resulting list is usually so inundated with potential winter visitors that it becomes extremely difficult to discern which species are directly dependent on the area for reproduction. The list of birds presented here is composed of those species which are considered to be potential breeders on KAFB. 
Finally, an attempt is made in this report to provide the information in a format which can be easily modified and updated by future researchers. The species lists are provided in a tabular format to allow easier transcription, insertion, deletion, reorganization, and other changes required by future changes in taxonomy, field verification, or to suit a special reporting need. Further, an attempt has been made to provide a standardized system of habitat classification. Although to do this for such a broad range of organisms is admittedly prone to oversimplification, its potential usefulness in developing specialized lists for specific habitat types (e.g., "grassland species") far outweigh the problems of generality.

\subsection{DESCRIPTION OF THE STUDY AREA}

The boundaries of KAFB encompasses an area of about 52,000 acres southeast of Albuquerque, New Mexico (Figure 1.1). This area can be subdivided into two large units which are distinct both politically and ecologically. The western unit is approximately 31,000 acres in size, 90 percent of which is owned by the Air Force and the rest is owned by the Department of Energy (DOE), primarily for use by Sandia National Laboratories, Albuquerque. The eastern unit is approximately 21,000 acres in size and is withdrawn from the Cibola National Forest by agreements with the Air Force and the DOE.

The western unit of KAFB lies on an elevated terrace between the Rio Grande and the Manzano Mountains. This terrace, known as the East Mesa (i.e., lying east of the Rio Grande), is generally flat, with a gentle westward slope of less than 2 percent. Two large arroyos dissect the western unit. Tijeras Arroyo runs southwestward across the northern part of the unit and Arroyo del Coyote runs northwestward through the central part, joining with Tijeras Arroyo before it crosses the western boundary of KAFB (Figure 1.2).

The elevation of the terrace within the western unit ranges from 5200 feet at the bottom of Tijeras Arroyo to approximately 6000 feet at the base of the Manzano Mountains. However, a small outlier range of mountains, known as the Four Hills, lies just within the unit on the east side. The highest peak of the Four Hills rises abruptly above the surrounding plains an additional thousand feet. 

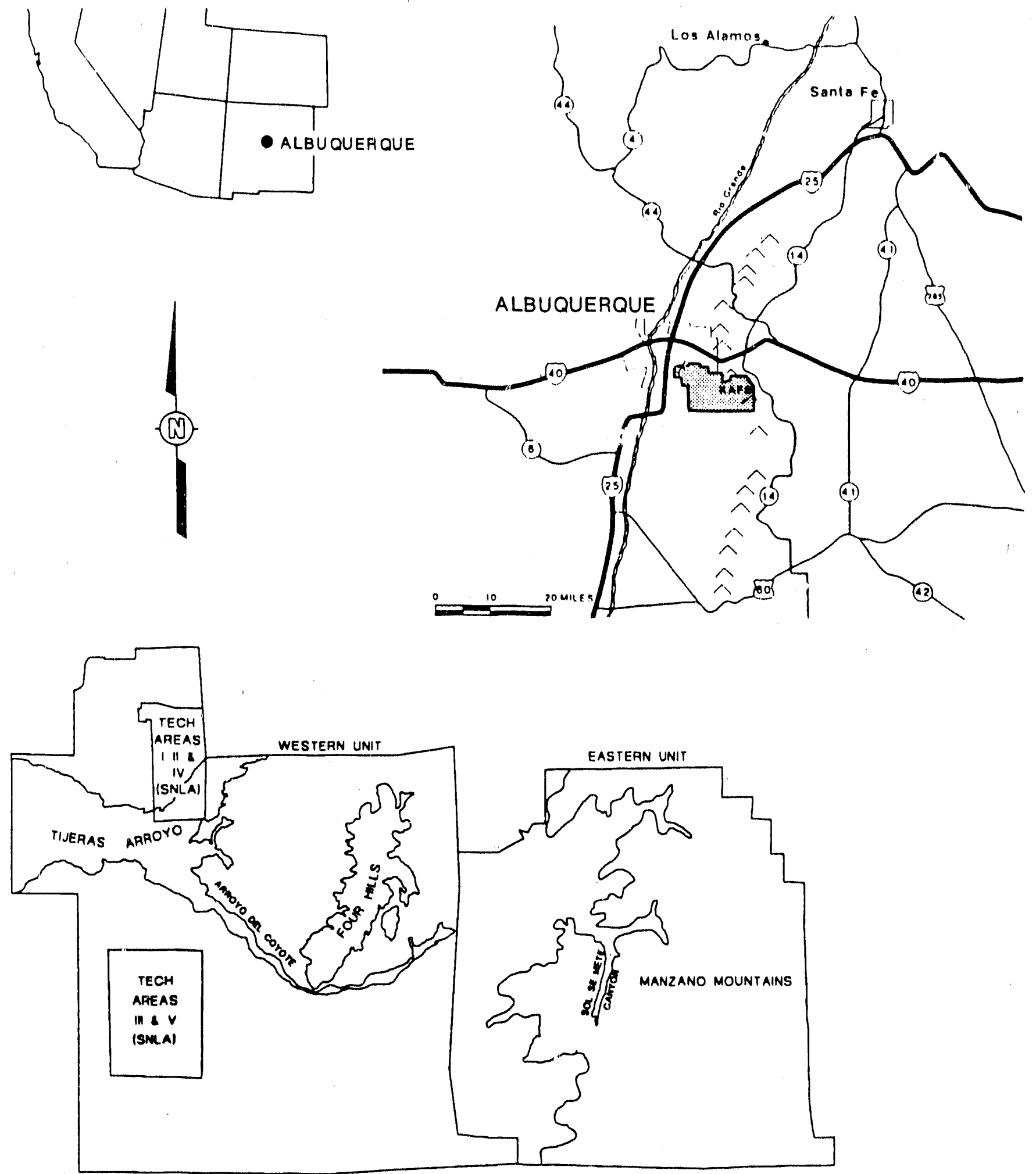

KIRTLAND AIA FORCE BASE $6000 \quad 0 \quad 6000$ FEET

FIGURE 1.1 LOCATION MAP OF KIRTLAND AIR FORCE: BASE AND SANDIA NATIONAL LABORATORIES, ALBUUUERQUE 


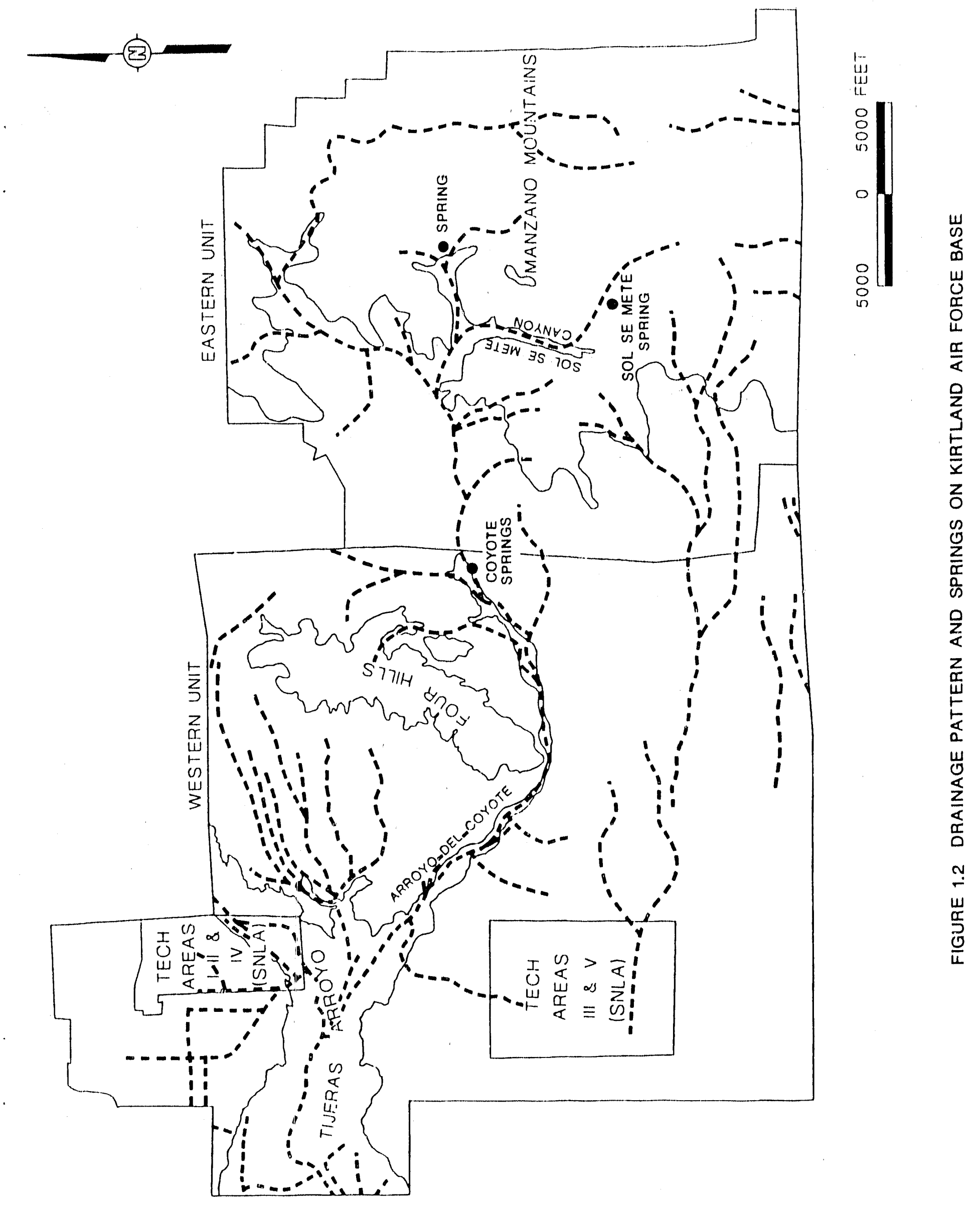


The ropography of the eastern unit is dominated by the Manzano Mountains. This unit ranges in elevation from about 6000 feet at the southwest corner to nearly 8000 feet at the site of the old Manzano Lookout Tower. The mountains within this unit are highly dissected by canyons, the major ones being Sol de Mete Canyon, Lurance Canyon, Madera Canyon, Bonita Canyon, and David Canyon. This section of low, highly eroded mountains which form a bridge between the rilain Manzano range to the south and the Sandia range to the north are sometimes referred to as the Manzanita Mountains.

The climate of the area is mild and dry. Average maximum and minimum temperatures on the mesa are $92^{\circ}$ and $65^{\circ} \mathrm{F}$, respectively, for July and $47^{\circ}$ and $24^{\circ} \mathrm{F}$, respectively, for January. Average annual rainfall is approximately 8 inches on the mesa and increases to 20 inches in the mountains.

\subsection{GEOLOGY AND SOILS}

KAFB straddles the eastern edge of the Rio Grande trough, delineated by a series of northsouth oriented faults that run through the center of the base. The Manzano Mountains represent a block uplift along three fault lines with steep west-facing slopes of exposed Precambrian metamorphic rock capped with Permian-aged limestones of the Madera and Sandia Formations. These uplifted limestone beds dip gradually eastward, providing the elevated, rolling terrain of the eastern slopes. The Four Hills are a separate uplift block from which the limestone cap has since eroded, leaving the underlying Precambrian granite fully exposed.

Fans of quaternary alluvium from the slopes and canyons if the Manzano Mountains grade into the flat miesa surface, composed of finer alluvial and eollan deposits. These Quaternary sediments are underlain by the Tertiary alluvium of the Santa Fe Formation, which is exposed along the cut-banks of the larger arroyos.

The soils of KAFB have been classified and mapped by the Soll Conservation Service (Hacker, 1977). A generalized soil map of KAFB is presented in Figure 1.3. The flat terrace surfaces are dominated by sandy loam solls. These include the Latene sandy loam, the Wink fine sandy loam, the Madurez loarny fine sand, and the Tome very fine sandy loam. The arroyo bottoms are generally Gila fine sandy loams, while the cut banks on the sides of the arroyo are classified as a hilly Bluepoint-Kokan association solls typified by exposures of the Santa Fe Formation. 
Nearer to the mountains, the slopes increase and the soils become coarser. On the east sido of the western unit, the solls are predominantly the Embudo gravelly fine sandy loam, the Tljeras gravelly fine sandy loam and the lldefonso gravelly sandy loam.

Alluvial slopes, or bajadas, at the bases of the mountains and within the canyons are dominated by very coarse soils. These include the Tesoja-Millett stony sandy loam and the Salas very gravelly loam complex. Above these solls are parent rock outcrops and shallow, young soils. The eastern slopes of the Manzano Mountains have gentler slopes and are dominated by the cobbly to stony loam soils in the Sois Series derived from weathered limestone.

\subsection{BIOLOGICAL COMMUNITY CLASSIFICATION}

Classification of the biological communities in this area is difficult due to its location in an area transitional between several major biological regions. In the Environmental Assessment for the Strategic Defenses Facility (Department of Energy, 1988), the blological community of the western unit is classified as the Grama-Galleta Steppe Section of the Colorado Plateau Province, in accordance with the ecoregion system of Bailey (1978). However, as Martin and Wagner (1974) point out, only the Rocky Mountain Woodland community (i.e., the pinyonjuniper association) was found to be truly representative of the community type. The remainder of the vegetation showed floristic influences frum the Great Basin desert, the Chihuahuan desert, the desert grassland, and the short-grass prairie.

In this report, the Blome classification system of Brown (1982) is used to classify the biological communities. This system offers several advantages over most community classification systems. The system is specific to the southwest, providing an excellent level of detall for use in New Mexico. It is based on both climatic zone (as a higher level of classification) and species assemblage (which includes both flora and fauna). It is also based on a digitized hierarchical system which can be further subdivided into more detailed levels as needed.

In accordance with this system, KAFB lies near the southern boundary of the Cold-temperate Climatic Zone. Within KAFB, the blological communities of the plains, arroyos, and lower slopes of the Manzano Mountains are dominated by the Great Basin Grasslands Blome; 
however, specles assoclated with the Plains Grassland Blome, which dominates east of the Manzano Mountains, are common. Sites with warmer and drier microclimates, such as south and west facing slopes and exposed plains, are expected to show greater blological affinitles to the Semidesert Grassland Blome of the Warm-temperate Climatic Zone. Such affinities were found by Martin and Wagner (1974) in Sol de Mete Canyon.

On the coarser solls of the bajadas, especially on the cooler and more moist north and east facing slopes, the cold-temperate grasslands give way to the Great Basin Conifer Woodland Blome, dominated by one-seed juniper (Juniperus monosperma) and Colorado pinyon (Pinus edulis). Elements of the Rocky Mountain Montane Conifer Forest Biome, such as ponderosa pine (Pinus ponderosa), and the Great Basin Montane Scrubland Blome, such as scrub-oaks (Quercus turbinella, $\underline{Q}$ grisea, and $\underline{Q}$. gambelii), were found in the more mesic locations in canyons and at higher elevations during the surveys by Martin and Wagner (1974).

\subsection{HABITAT TYPES}

In the species lists contained in this report, an attempt has been made to standardize the habitat classification for each species. The definition of habitat type is based primarily on the soil and biome classifications described above. The categories used are as follows:

Grasslands - Flat terrace surfaces occupied by undisturbed Latene, Wink, Madurez, Tome, Tijeras, Embudo, and Ildefonso solls. These soils are sandy loams to gravelly sandy loams with slopes less than 5 percent. The provailing biomes are cold-temperate grasslands.

Arroyos - Generally limited to the Gila soil of Tijeras Arroyo and Arroyo del Coyote and the adjacent cut banks of the Bluepoint-Kokan association. The prevailing biomes are cold-temperate grasslands, semidesert grasslarid, and Great Basin riparian wetland.

Woodlands - Areas of weil developed pinyon-juniper woodland (Great Basin Conifer Woodland). In this area, woodlands are typically found on the north and east facing slopes of the mountains on all gravelly to rocky soils.

Canyons - Areas within canyons which are more moist than the surrounding slopes due to the concentration of runoff and protecticn from exposure afforded by the adjacent slopes. Solls are typically Tesoja-Millett stony sandy loam or in the Seis Series. The biomes present may range from Great Basin riparian wetland to the Rocky Mountain Montane Conifer Forest. 
Rocky slopes - 'This is a genel'al term used to indicate a species' affinity to rock outcrops or stony soil at any elevation. Soils are typically in the Salas or Seis Series. Biomes are variable.

Lower' slopes - Generally the lower part of the bajadas at the bases of mountains with gravelly to stony loam soils and slopes between 5 and 20 percent. The term "lower" is used in an ecological sense as well as a physical sense. A lower slope may be found at relatively high elevation if the exposure conditions are such that the microclimate is equivalent to inat of the lower elevation (i.e., being warmer and drier). These areas are usually transitional between the cold-temperate and semidesert grasslands and the Greai Basin Conifer Woodland.

Higher elevations - This term is also used in the ecological sense, meaning an area with sufiicient protection from exposure to have a microclimate equivalent to the Rocky Mountain Montane Forest Biome. On the KAFB, this habitat is generally limited to north facing slopes in the upper reaches of canyons. Soils are typically very rocky.

Wetlands - Any area with permanently saturated soil or permanent standing water. Wetlands may occur as a small, isolated unit within any of the major soil types or biomes.

Disturbed ground - Areas on which the natural soil structure has been physically altered by human activity.

Buildings - Areas near or significantly influenced by man-made structures. These can include buildings, power lines, fences, roads, lawns, planted trees, engineered frames, storage tanks, etc.

\subsection{PROTECTED SPECIES AND SENSITIVE HABITATS}

Both Federal and State laws provide protection to species and distinct subspecies, variuties, and populations which are either in danger of extinction now, or may become so in the near future. Such protection is afforded to any species regardless of taxonomic relationships; current lists of protected species include vertebrates, invertebrates, and plants. In cases where the survival of an endangered or threatened species is closely linked to protection of its habitat, critical habitat status may be conferred to the geographical area containing the habitat.

No species listed as endangered or threatened by the U.S. Fish and Wildlife Service (50 CFR 17.11 and 17.12, as amended through March 14, 1990), the New Mexico Department of Game and Fish (Regulation 657, January 9, 1988), and the New Mexico Energy, Minerals, and Natural Resources Department (NRD Rule No. 85-3, October 28, 1985) are known to occur on KAFB. Five species listed by the state may potentially occur on KAFB. These are: 
- Willow Flycatcher (Empidonax trailli extimus) State Endangered Group 2. This is an unlikely breeiding species in the canyons and near water.

- Gray Vireo (Vireo vicinior) State Endangered Group 2. This is also an unlikely breeding species in the canyons.

- Spotted Bat (Euderma maculatum) State Endangered Group 2. This species has been reported from Bernalillo County (New Mexico Department at Game and Fish, no date), but is unlikely in the KAFB rrea.

- Grama Grass Cactus (Pediocrctus papyracanthus) State listed endangered plant. Potentially occurring in undisturbed gresslands.

- Pincushion Cactus (Manmillaria wrightii) State list $\rfloor\rfloor$ endangered plant. Potentially occurrir $z$ in sandy to rocky soils.

No State or Federally listed amphibian, reptile, or invertebrate is expected to occur on K.AFB. There are no areas of critic al habitat on KAFB.

In addition to the protection of endangered species and critical habitat provided by State and Federal endangered species laws, a general policy of conservation of all nongame fish and wildlife species and their habitats by Federsi departments and agencies (to the maximum extent practicable and consistent with their siatutory responsibilities) is set forth in the Fish and Wildlife Conservation Act of 1980 (16 U.S.C. 2901 et seq.). To this end, arsas of important and sensitive habitat types, particularly wetlands and riparian zones, should be given special consideration in plaining and development activities on KAFB.

Three springs n KAFB provide small areas of natural wetlands (Figure 1.2) The largest of these, Coyote Springs, is confined to an: area of only a few acres and consists of several seeps and springs. One of these has been developed into a rock-lined well. The high water table in the area supports a number of Fremont cottonwoods and salt-cedars. Cattails, rushes, and wetland grasses almost completely cover the areas of shallow standing water and permanently moist soil. There are no significant areas of open water at this site.

The other two springs are smail and are loratec in the canyons above Coyote Springs. These have been partially developed and are not assuciated with significant wetland habitat, although they do provide a water source for local wilc 'ie. 
Riparian habitat coriditions on KAFB are fair to poor outside of the canyons. Tijeras Arroyo and Arroyo del Coyote are principally vegetated with shrubs such as rabbitbrush (Chrysothamnus spp.). Near the Manzano Mountains, Arroyo del Coyote is densely vegetated with salt-cedar. The canyon bottoms, though not heavily wooded, have a good diversity of shrubs and small trees. The lack of permanent water in these canyons (except at the springs) limits their quality as wildlife habitat. 


\subsection{LIST OF AMPHIBIANS}

No species were deleted from the original lists. The Woodhouse's toad is the most conspicuous addition to this list (Table 2.1). The occurrence of canyon treefrogs on KAFB will depend upon the existence of permanent rocky pools in the canyons. Based on available descriptions, it is uncertain whether adequate habitat exists for this species. Taxonomy and nomenclature in this list follow Smith (1978). Ranges are based on Stebbins (1954). 
TABLE 2.1

LIST OF AMPHIBIANS WITH A MODERATE TO HIGH PROBABILITY OF OCCURRENCE ON KAFB

\begin{tabular}{|c|c|c|c|}
\hline SCIENTIEIC NAME & COMMON NAME & STATUS & HABITAT \\
\hline Order: Sallentla & & & \\
\hline \multicolumn{4}{|l|}{ Fam1ly: Pelobat1dae } \\
\hline Spea hammondl hammond 1 & Western Spadefoot & $\mathbf{R}$ & Grasslands/arroyos \\
\hline Spea bomblfrons & Plalns Spadefoot & $\mathbf{R}$ & Grasslands/arroyos \\
\hline \multicolumn{4}{|l|}{ Famlly: Bufonldae } \\
\hline Bufo punctatus & Red-spotted load & 0 & Grass lands / arroyos / canyons \\
\hline Bufo woodhouse 1 & Woodhouse's Toad & $N$ & Grass lands/arroyos / canyons \\
\hline Bufo debilis instalor & Plalns Green Toad & $\mathbf{R}$ & Grasslands/arroyos \\
\hline Bufo cognatus & Great Plains Toad & 0 & Grasslands/arroyos \\
\hline \multicolumn{4}{|l|}{ Order: Caudata } \\
\hline \multicolumn{4}{|c|}{ ramlly: Ambystomat Ldae } \\
\hline Ambystoma tigrinum mavortium & Tlger Salamander & $R$ & Arroyos/canyons/wet Lands \\
\hline 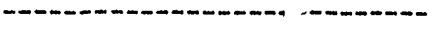 & $--m-m--m-m-m-m$ & $-\cdots$ & 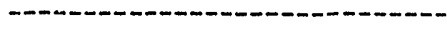 \\
\hline Status: 0 - Unchanged from 0 & orlglnal $118 t$ & Renamed & $N$ - New species to list \\
\hline
\end{tabular}

TABLE 2.2

LIST OF AMPHIBIANS WITH A LOW PROBABILITY OF OCCIJRRENCE ON KAFB

SCIENTIFIC NAME
Order: Sallentia
Fam1ly: Pelobatidae
Scaphlopus couch
Fam1ly: Hylldae
Hyla arenlcolor
Family: Ranidae
Rana plpiens

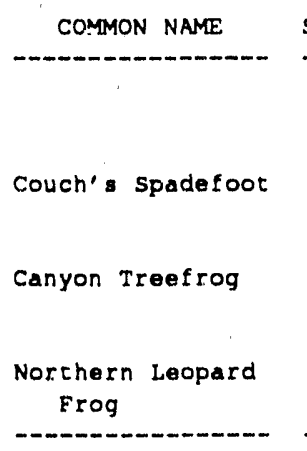

STATUS HABITAT

Status: 0 - Unchanged from orlginal llst $R$ - Renamed $N$ - New specles to 11 st 


\subsection{LIST OF REPTILES}

No species were deleted from the original list. Seventeen species have been added; however, most of these are listed as having a low probability of occurrence (Tables 3.1 and 3.2 ). The most significant changes are with the whiptail lizards (genus Cnemidophorus). Several species of this genus are parthenogenic, able to reproduce asexually, a characteristic apparently arising frum hybridization between sexually reproducing species (Smith and Brodie, 1982). Two species of parthenogenic whiptails, the desert grassland whiptail and the New Mexico whiptail, have been added to the list. The sexually reproducing western whiptail may also occur as a northern outlier population. Taxonomy and nomenclature follow Smith and Brodie (1982). Ranges are based on Stebbins (1954). 
TABLE 3.1

\section{LIST OF REPTILES WITH A MODERATE TO HIGH PROBABILITY OF OCCURRENCE ON KAFB}

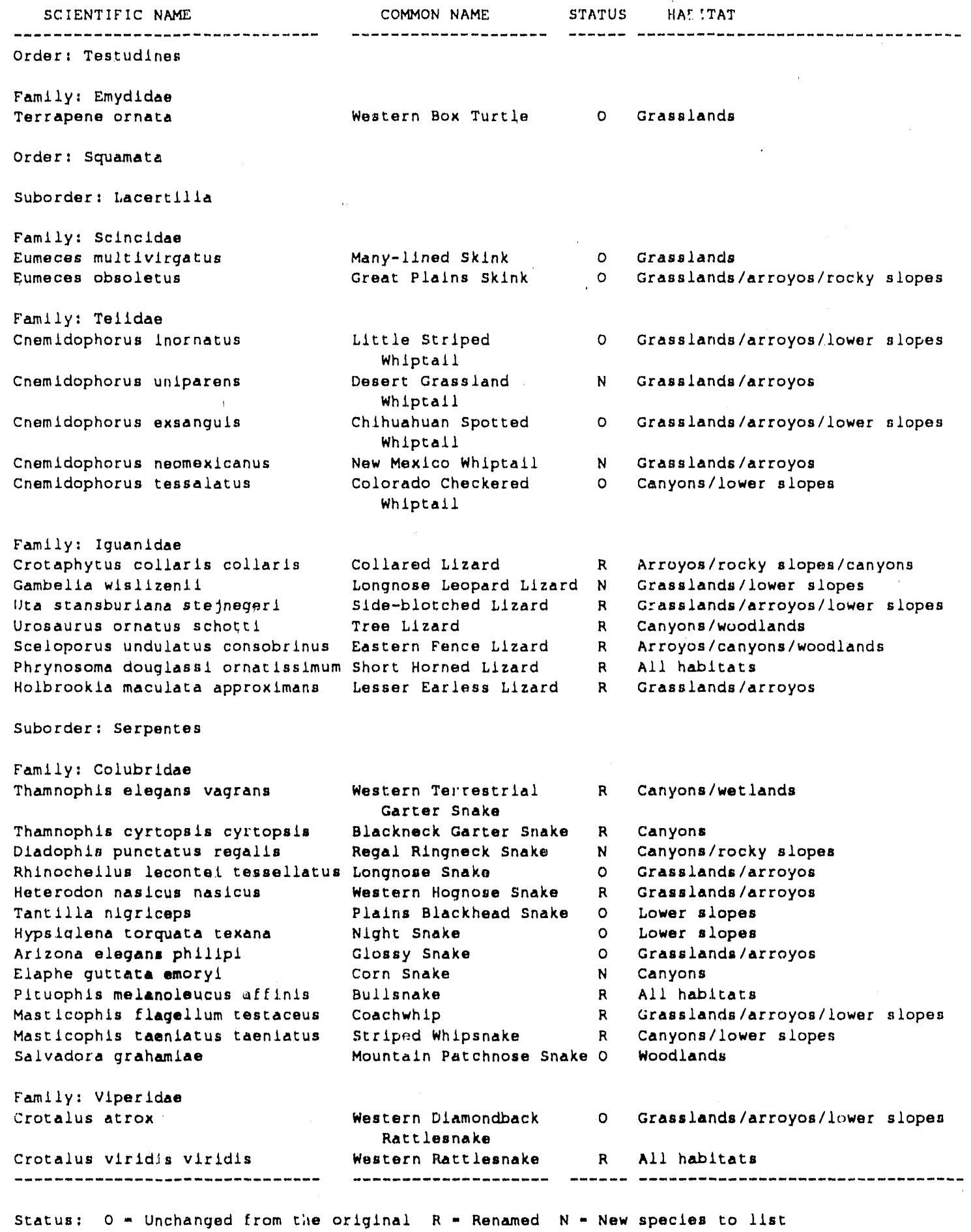


TABLE 3.

\section{LIST OF REPTILES WITH A LOW PROBABILITY OF OCCURRENCE ON KAFB}

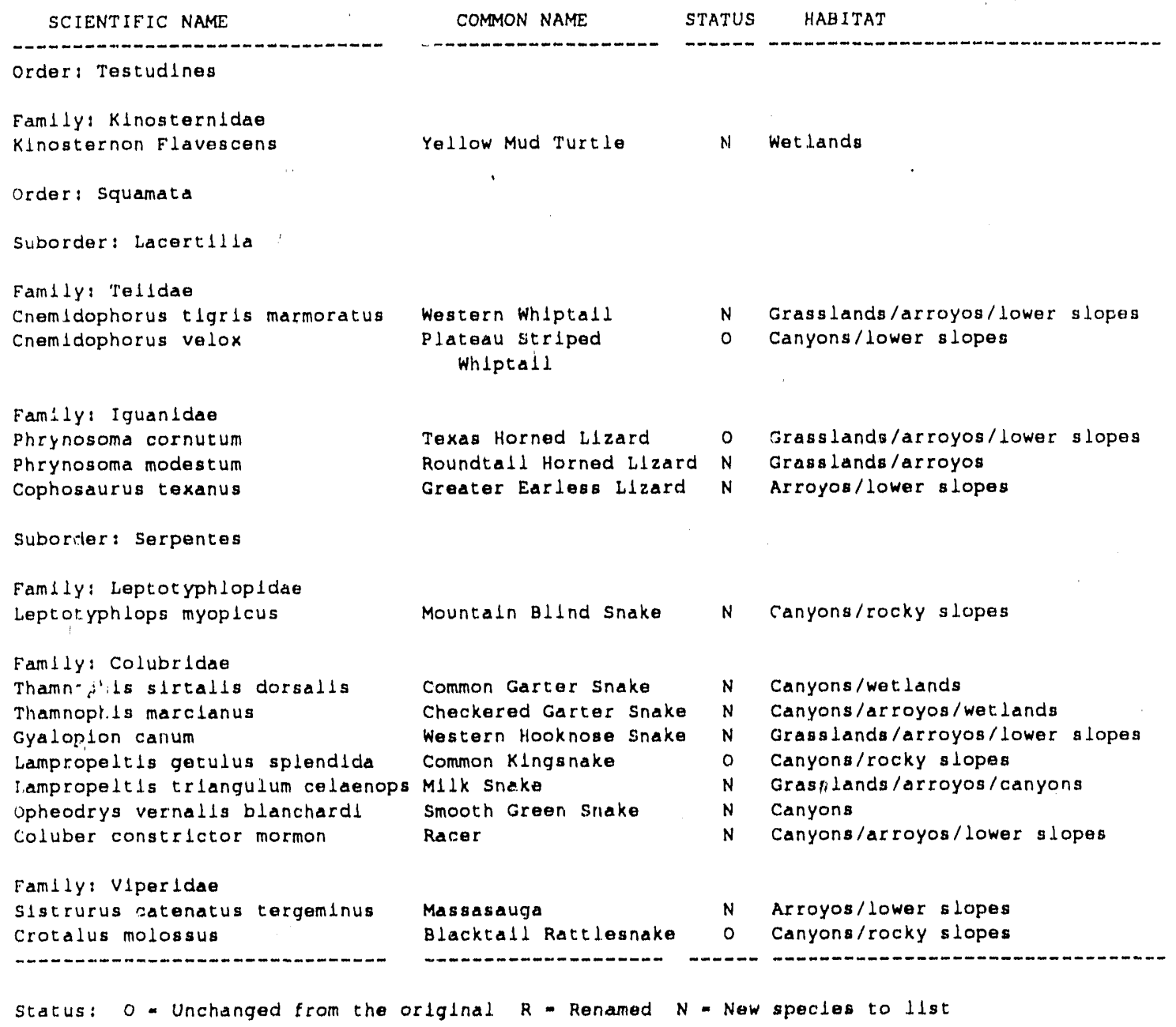




\subsection{LIST OF BIRDS}

This list (Table 4.1) attempts to inventory all species which are potential breeders on the KAFB hased on descriptions of avallable habitat types. It has been assumed that there is insufficient standing water for waterfowl breeding. Most deletions from the original list are migrant species. Additions and deletions are based on the breeding ranges described in Hubbard (1978). Taxonomic order is based on Robbins, et al. (1983). Common names follow those of the National Geographic Soclety (1987). 
TABLE 4.1

\section{LIST OF POTENTIAL BREEDING BIRDS FOR KAFB}

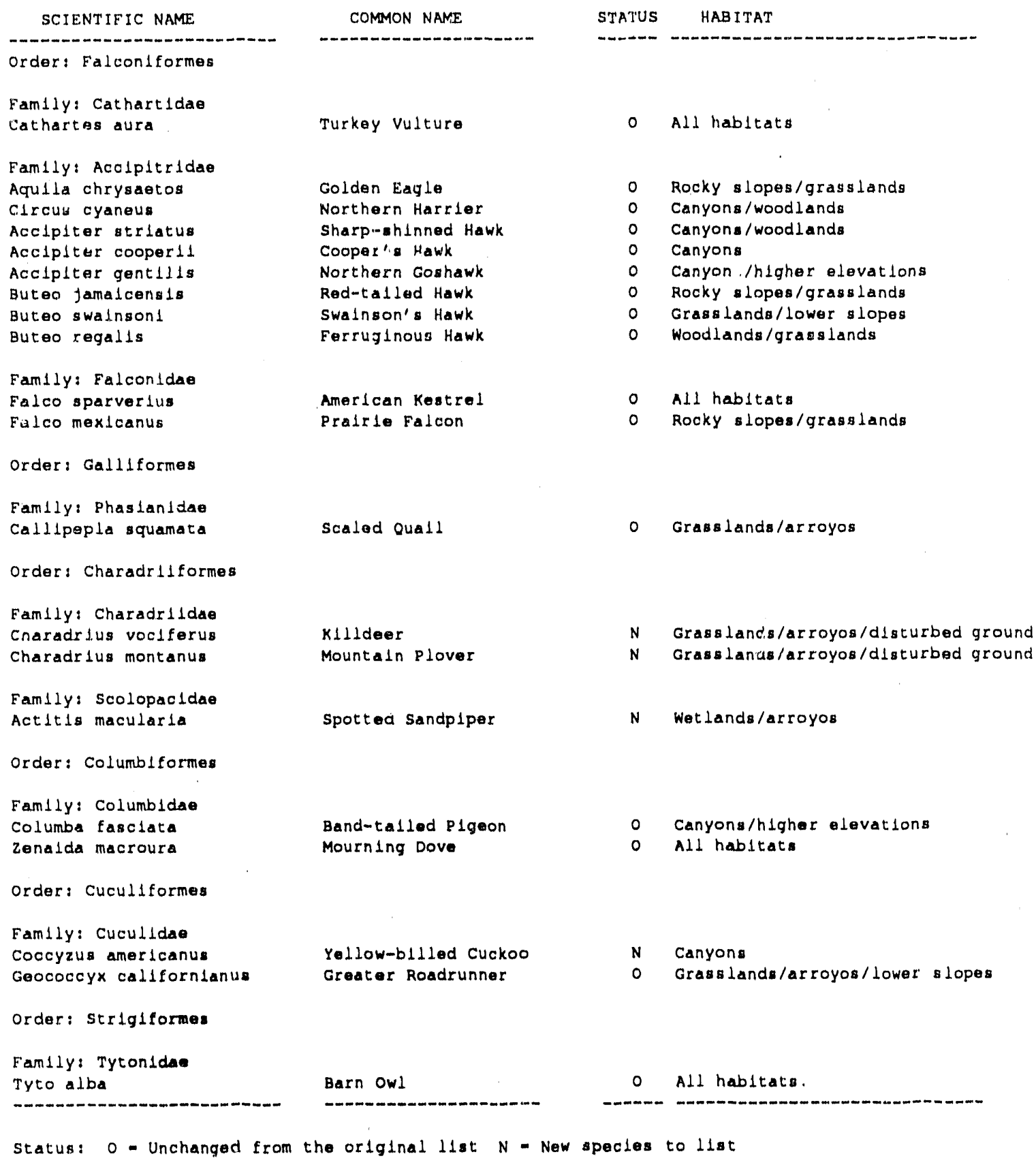


TABLE 4.1

(CONTINUED)

\section{LIST OF POTENTIAL BREEDING BIRDS FOR KAFB}

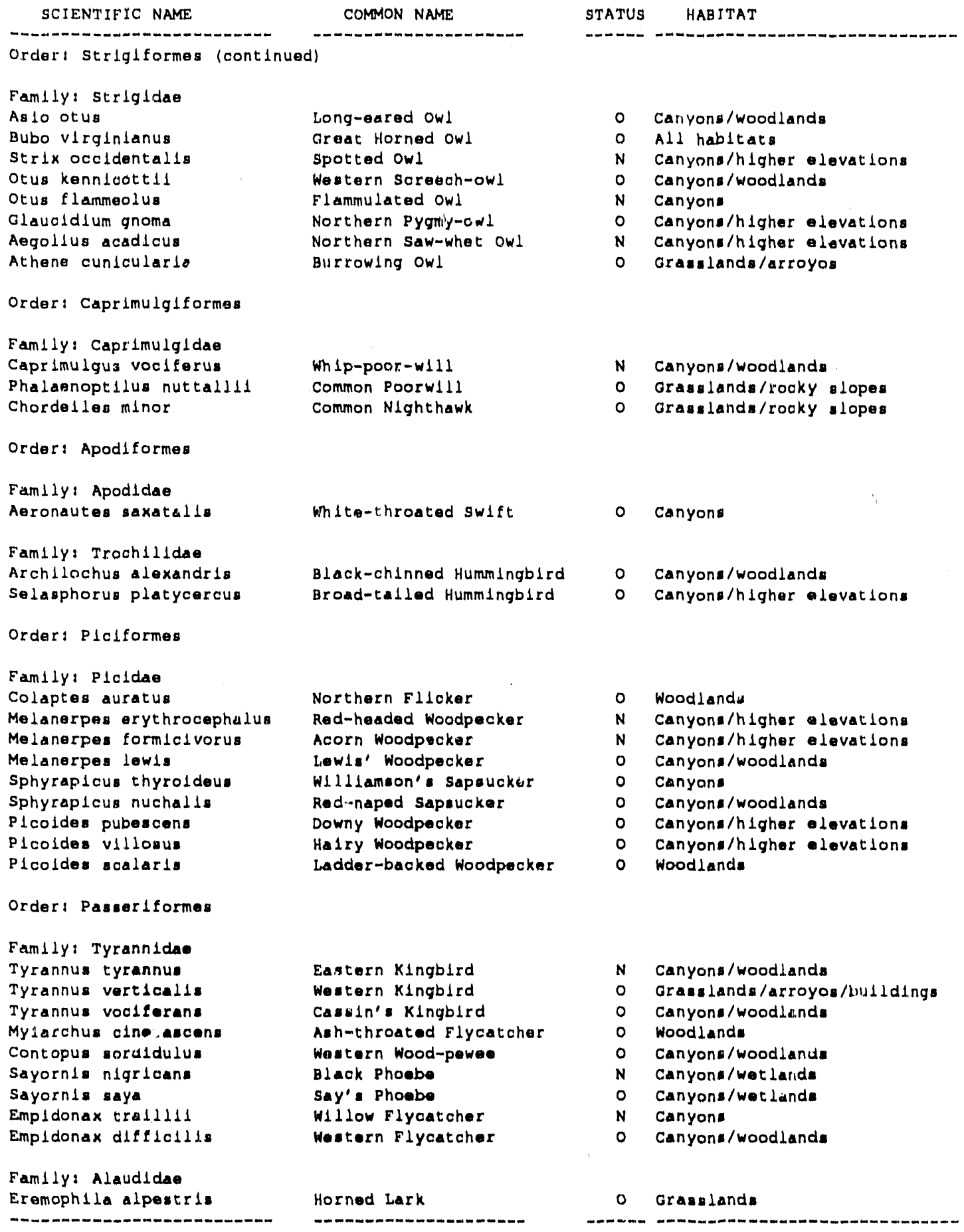

Status: 0 - Unchanged from the orlglnal llat $N$ - New opecies to llat 
TABLE 4.1

(CONTINUED)

\section{LIST OF POTENTIAL BREEDING BIRDS FOR KAFB}

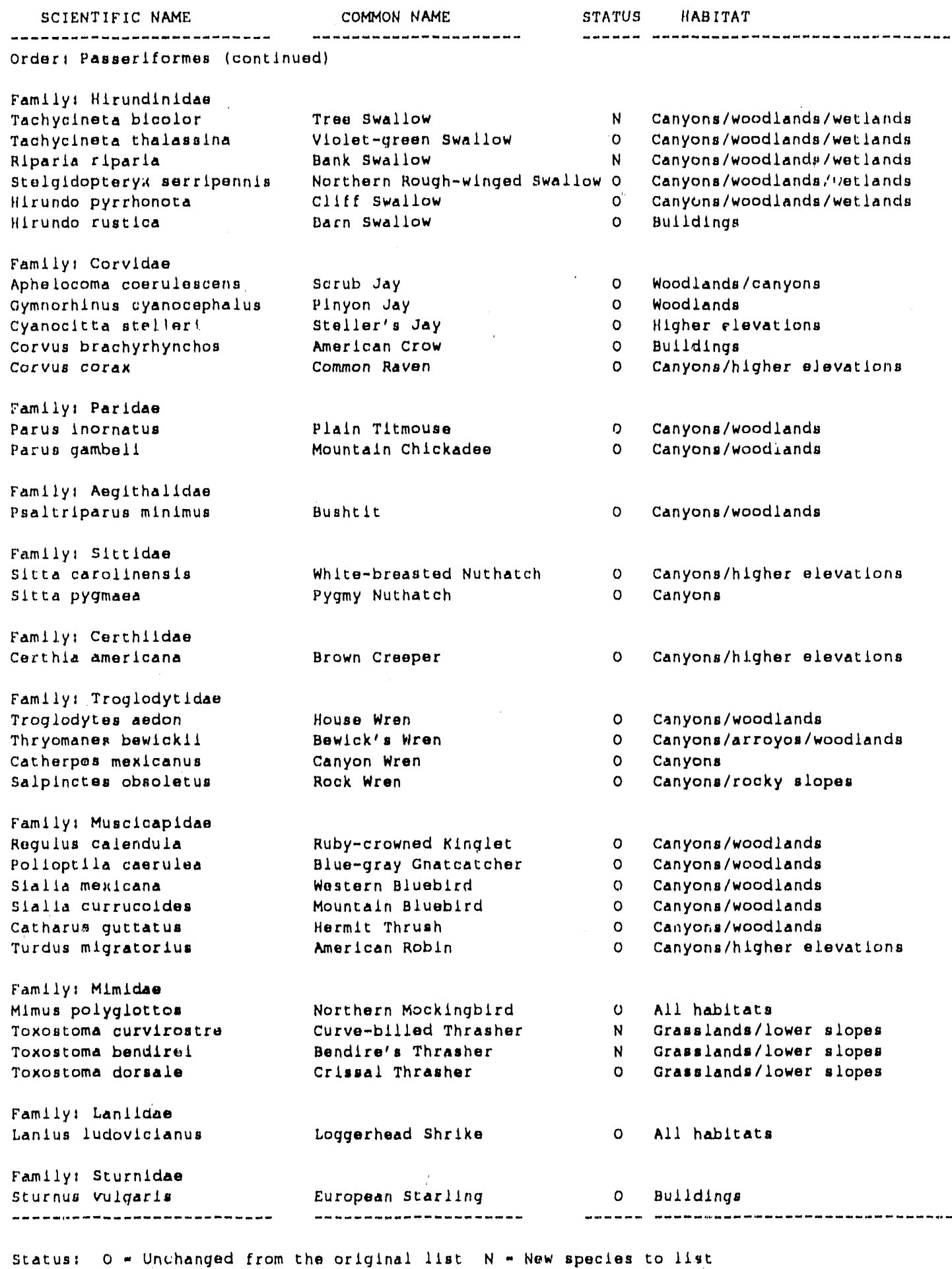


TABLE 4.1

(CONTINUED)

\section{LIST OF POTENTIAL BREEDING BIRDS FOR KAFB}

\begin{tabular}{|c|c|c|c|}
\hline SCIENTIFIC NAME & COMNON NAME & STATUS & HABITAT \\
\hline \multicolumn{4}{|c|}{ Order I Passerlformes (continued) } \\
\hline & 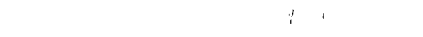 & & \\
\hline \multicolumn{4}{|l|}{ Famlly: VIreonldae } \\
\hline Vlreo vicinlor & Oray VIreo & N & Canyons \\
\hline Vlroo solltarlus & Solltary Vlreo & 0 & Canyons / woodlands \\
\hline VIreo glivus & Warbiling Vireo & 0 & Canyons \\
\hline \multicolumn{4}{|l|}{ Famllyt Emberlzldau } \\
\hline Vermivora vlrglnlae. & VIrglala's Warbler & 0 & Canyons/woodlands \\
\hline Dendrolca coronata & Yol low-rumped Warbler & 0 & Canyons/woodlands \\
\hline Dendrolca nlgrescens & Black-throated Oray Warbler & 0 & Canyons / woodlands \\
\hline Dendrolea graclae & Orace's Warbler & $N$ & Canyons / woodlands \\
\hline Dendrolca petechla & Yellow Warbler & 0 & Canyons/woodlands \\
\hline Oporornls tolmiel & Macollllvray's Warbler & 0 & Canyons/woodlands \\
\hline Wilsonla pustlla & W11son's Warbler & 0 & Canyons/woodlands \\
\hline Geothlypls trichas & Common Yol lowthroat & $\mathrm{N}$ & Canyons / woodlands / wet lands \\
\hline Icterta virens & Yellow-breasted chat & 0 & Canyons/wet lands \\
\hline \multirow{2}{*}{\multicolumn{2}{|c|}{$\begin{array}{l}\text { Subfaml1y: Thrauplnae } \\
\text { Plranga Ludovlclana }\end{array}$}} & 1 & \\
\hline & & 0 & Canyons/woodlands \\
\hline Plranga rubra & summer Tanager & $N$ & Canyons/woodlands \\
\hline Plranga flava & Hepat 1c Tanager & 0 & Canyons/woodlands \\
\hline \multicolumn{4}{|l|}{ Subfam 1 ly: Cardinalinae } \\
\hline Pheuct lcus melanocephalus & Black-hesaded Grosbeak & 0 & Canyons/woodlands \\
\hline Sulraca caerulea & Blua Grosbeak & 0 & Canyons/woodlands \\
\hline Passelina oyanea & Indlgo Bunt Ing & 0 & Canyoris/woodlands \\
\hline Passerina amoena & Lazuld Bunt Ing & 0 & Canyons/woodlands \\
\hline \multicolumn{4}{|l|}{ Subfam 11y: Emberlz1nae } \\
\hline P1p1lo Chlorurus & Green-tal led Towhee & 0 & Canyons/woodlands \\
\hline PIp1 lo erythrophthalmus & Ru fous-s lded Towhee & 0 & Canyons/hlgher elevat lons \\
\hline P1P110 fuscus & Brown Towhee & 0 & Grasslands/arroyos/lower slopes \\
\hline Melosplza melodia & Song sparrow & 0 & Canyons / wet Lands \\
\hline Chondesces grammacus & Lark Sparrow & 0 & Grasslands/arroyos/lower slopes \\
\hline Amphlsplza blllneata & Black-throated sparrow & 0 & Grasslands/arroyos/lower slopes \\
\hline Almophlla ruflceps & Rufoug-crowned sparrow & 0 & Grasslands/arroyos/lower s Lopess \\
\hline Splzella passerina & Chlppling sparrow & 0 & Canyons/woodlands \\
\hline Splzella atrogularls & Black-chlnned Sparrow & 0 & Canyons / woodlands \\
\hline \multicolumn{4}{|l|}{ Subtamlly: Icterlnae } \\
\hline sturnella neglecta & Western Meadowlark & 0 & Grasslands/lower slopes \\
\hline Agelalus phoentceus & Red-winged Blackbled & N & Wetlands (oattall marshes) \\
\hline Molothrus ater & Brown-headed Cowblid & 0 & All habltats \\
\hline Qulscalus quiscula & Commion Gracklo & $N$ & Butldings \\
\hline Qulscalus mexlcanus & Great-talled Gracklo & N & Bulldings \\
\hline Icterus parlsorum & scotic's orlole & 0 & Canyons / woodlands \\
\hline Icterus galbula & Northern Orlole & 0 & Canyons/woodlands \\
\hline \multicolumn{4}{|l|}{ Famlly: Frlngld11dae } \\
\hline Carduelds psaltria & Lesiser Goldf lnch & 0 & Grasslands/arroyos \\
\hline Earpodacu mextcanus & Houlse Finch & 0 & All habltat. \\
\hline \multicolumn{4}{|l|}{ Famlly: Passarldae } \\
\hline Passer domesticus & House Sparrow & 0 & Bulldlngs \\
\hline 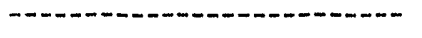 & $-\cdots--m-m-n-m-n-m-m$ & $-\infty-\infty$ & 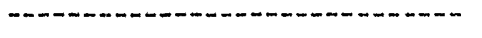 \\
\hline
\end{tabular}

Stacus: 0 - Unchanged from the orlglnal list $N$. New specles to list 


\subsection{LIST OF MAMMALS}

Three specles were deleted from the original list as being highly unlikely: the black-talled prairle dog, the hooded skunk, and the pronghorn antelope. Six specles were added to the primary list (Table 5.1) and fourtoen are suggested as potentlally occurring, but with a low probability (Table 5.2). All changes are based on Findley, et al. (1975). 


\section{TABLE 5.1}

\section{LIST OF MAMMALS WITH A}

\section{MODERATE TO HIGH PROBABILITY OF OCCURRENCE ON KAFB}

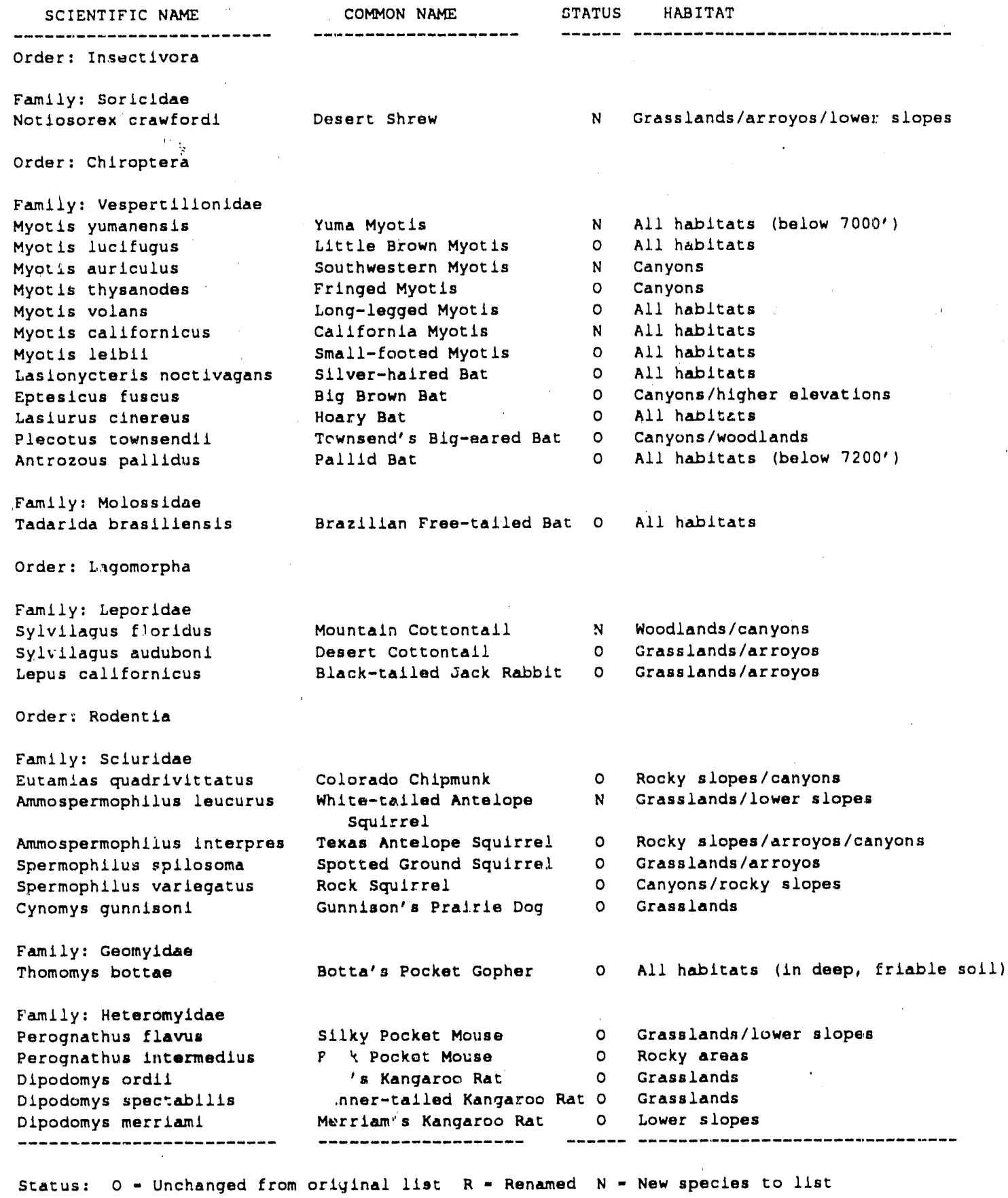


TABLE 5.1

(CONTINUED)

\section{LIST OF MAMMALS WITH A MODERATE TO HIGH PROBABILITY OF OCCURRENCE ON KAFB}

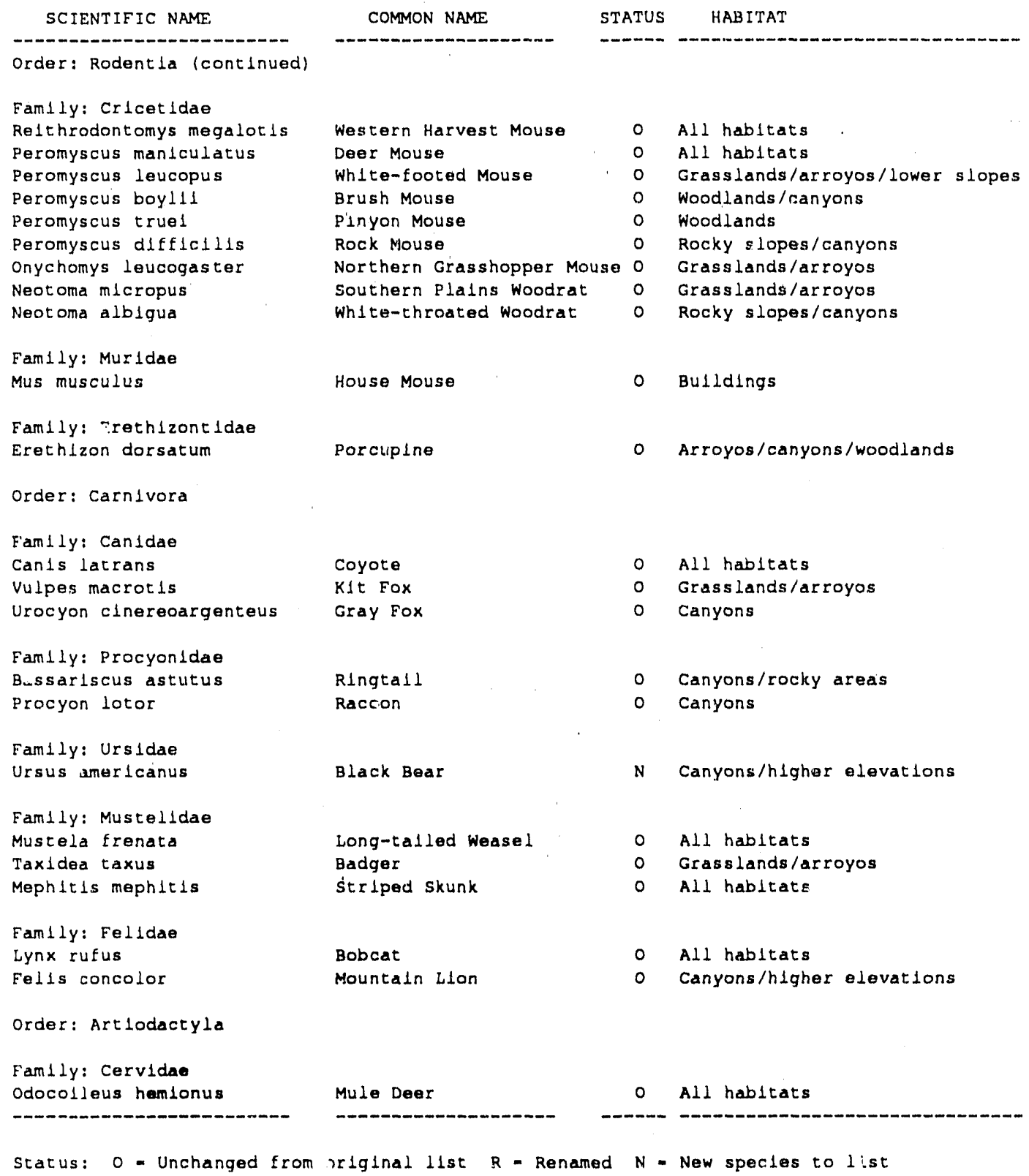


TABLE 5.2

\section{LIST OF MAMMALS WITH A \\ LOW PROBABILITY OF OCCURRENCE ON KAFB}

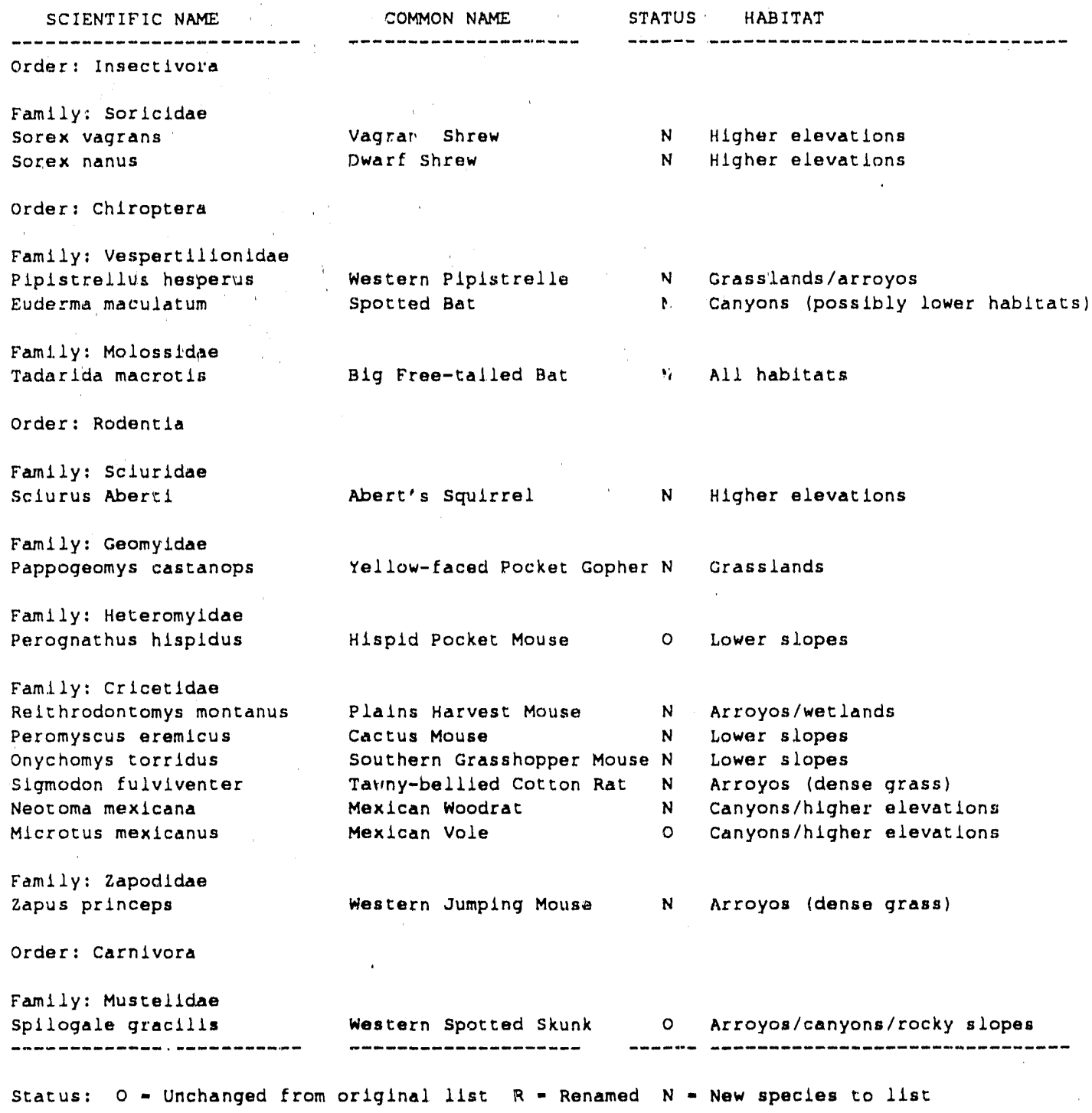




\subsection{LIST OF PLANTS}

Few species of plants were added to the original list and none were deleted except by taxonomic recombination (Table 6.1). The list of cactl is based on Benson (1982). All other changes are based on Martin and Hutchins (1980). 
TABLE 6.1

\section{LIST OF PLANTS WITH A \\ MODERATE TO HIGH PROBABILITY OF OCCURRENCE ON KAFB}

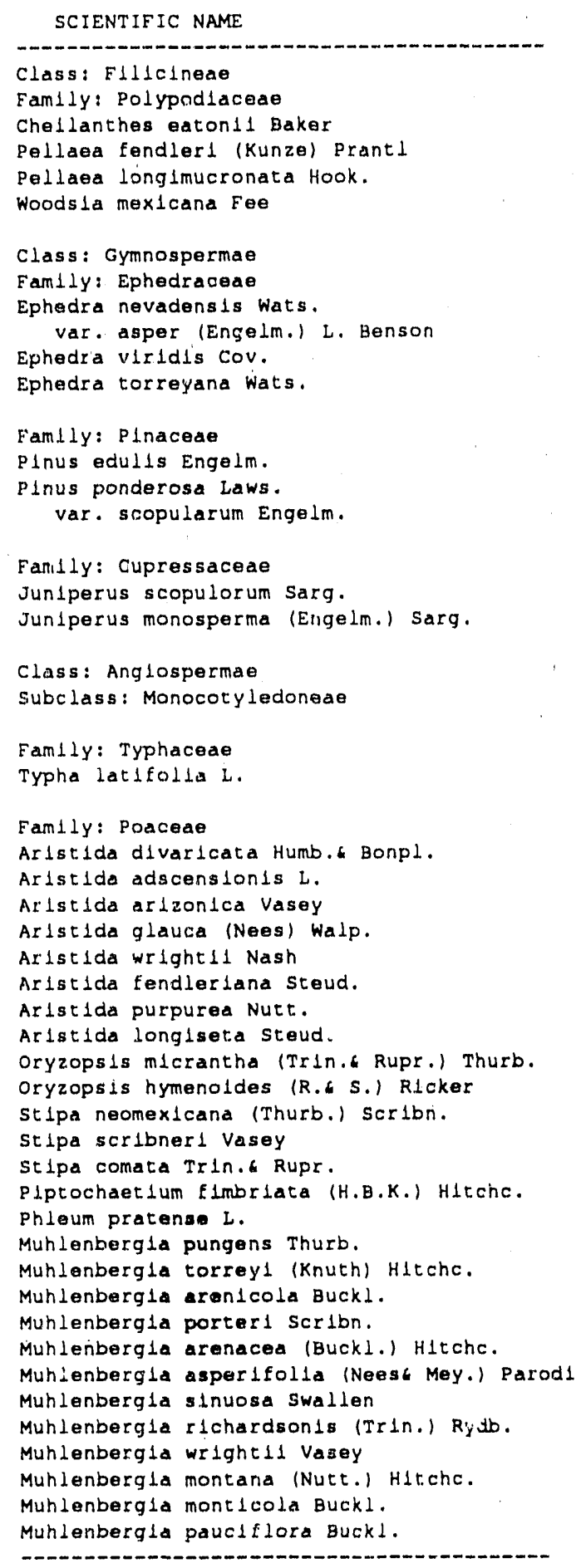

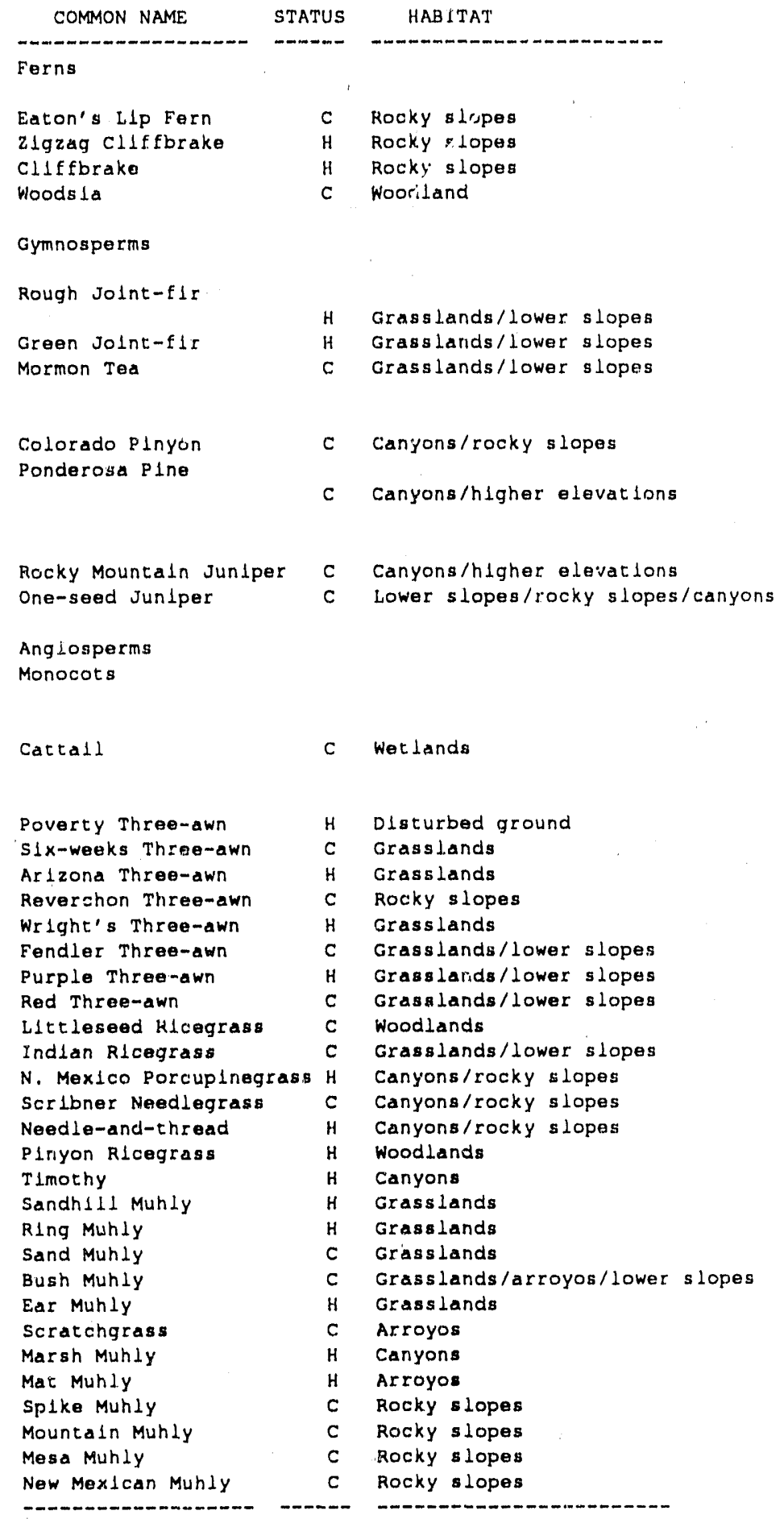

Status: C. Conflrmed by collection (Martin and Wagner, 1974) H - Hypothet lcal 
TABLE 6.1

(CONTINUED)

\section{LIST OF PLANTS WITH A MODERATE TO HIGH PROBABILITY OF OCCURRENCE ON KAFB}

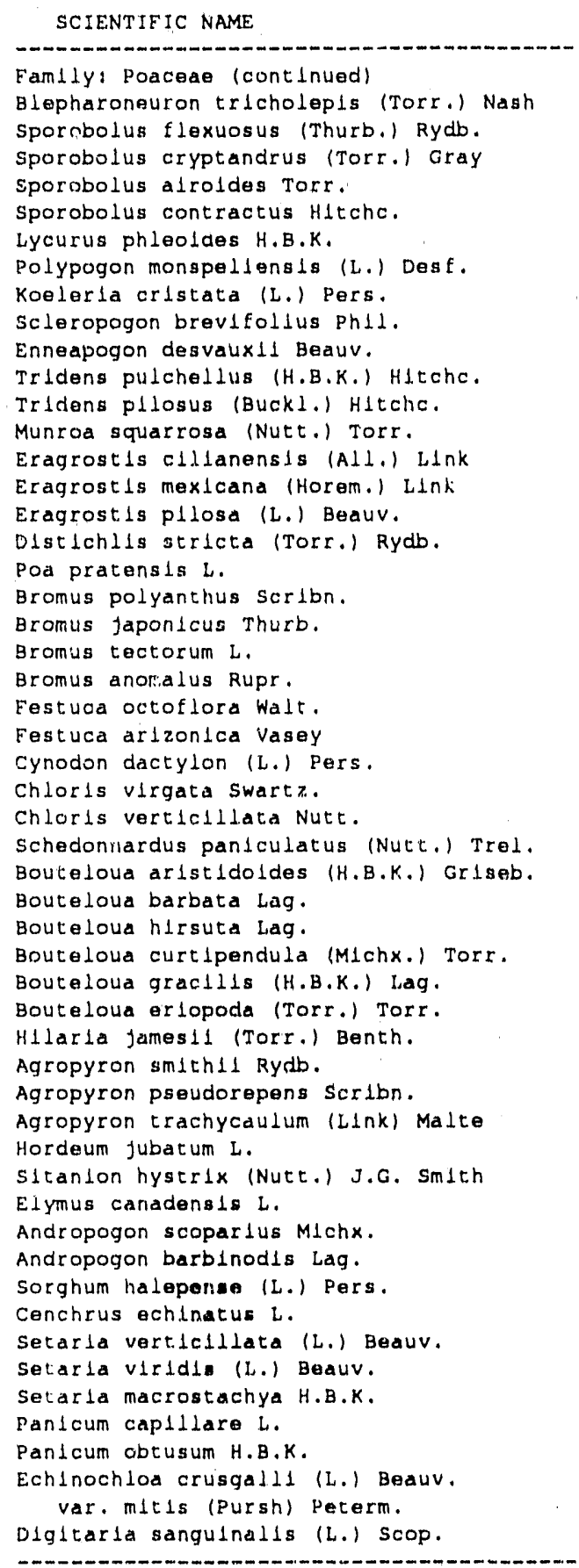

\begin{tabular}{|c|c|c|}
\hline COMMON NAME & STATUS & HABITAT \\
\hline 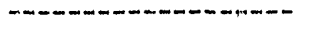 & -...m-n & 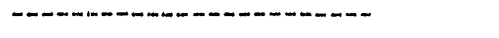 \\
\hline Plne Dropsead & $H$ & Woodlands \\
\hline Mesa Dropseed & $\mathrm{C}$ & Grasslands \\
\hline Sand Dropseed & $c$ & Ģrass lands \\
\hline Alkald Sacaton & G & Arroyos \\
\hline Splke Dropseed & C & Orass lands / arroyos \\
\hline Wolftall & H & Rocky s lopes \\
\hline Rabbltfoot Grass & $\mathrm{C}$ & Wet Lands \\
\hline Junegrass & $H$ & Woodlands/canyons \\
\hline Burro Grass & c & Grasslands \\
\hline Splke Pappusgrass & $\mathrm{C}$ & Grasslands/arroyos/lower s lopes \\
\hline Fluffyrass & $\mathrm{C}$ & Grasalands/dLsturbed ground \\
\hline Halry Tridens & $\mathrm{C}$ & Grasslands \\
\hline False Buffalo Grass & c & Grass Lands \\
\hline st Inkgrass & C & D1sturbed ground \\
\hline Mexlcan Lovegrass & $H$ & Dlsturbed ground \\
\hline Ind la Lovegrass & $\mathrm{C}$ & Dlsturbed ground/rocky slopes \\
\hline Desert Saltgrass & $\mathrm{C}$ & Arroyos \\
\hline Kentucky Bluegrass & $\mathrm{C}$ & Canyons /arroyos \\
\hline Footh1lda Bronie & 4 & Canyong/rocky slopes \\
\hline Japanese Chess & $\mathrm{C}$ & Dlsturbed ground \\
\hline Downy Chess & $\mathrm{C}$ & DLsturbed ground \\
\hline Nodding Brome & $\mathrm{H}$ & Canyons \\
\hline Slx-weeks Fescue & $H$ & Grasslands/arroyos \\
\hline Arlzona Fescue & $H$ & Canyons/rocky siopes \\
\hline Bermuda Grass & $\mathrm{C}$ & Arroyos/canyons/disturbed ground \\
\hline Faathery Fingergrass & $\mathrm{C}$ & Disturbed ground \\
\hline WLamili Grass & $\mathrm{C}$ & DLsturbed ground \\
\hline Tumble Grass & $\mathrm{C}$ & Grasslands \\
\hline Needle Grama & $\mathrm{C}$ & Grasslancis/dLsturbed ground \\
\hline Slx-weeks Grama & $\mathrm{C}$ & Grasslands/dlsturbed ground \\
\hline Hadry Grama & H & Grasslands \\
\hline Slde-oats Grama & $\mathrm{C}$ & Canyons/rocky slopes \\
\hline Blue Grama & $\mathrm{C}$ & Grass lands/Lower slopes \\
\hline Black Grama & $\mathrm{C}$ & Grasslands \\
\hline Galleta & $\mathrm{C}$ & Grasslands/arroyos/lower slopes \\
\hline Western Wheatgrass & c & Arroyos \\
\hline False Quackgrass & $H$ & Arroyos / canycins \\
\hline Slender Wheatgrass & $H$ & Arroyos \\
\hline Foxtall Barloy & $\mathrm{C}$ & Disturbed ground \\
\hline squirreltall & $\mathrm{c}$ & Grasslands/arroyos/lower slopes \\
\hline Canada WLId Rye & $\mathrm{C}$ & Arroyos / canyons \\
\hline Lltt le Bluestem & $H$ & Rocky s lopes \\
\hline Cane Beardgrass & $H$ & Grasslands/arroyos/lower slopes \\
\hline Johnson Grass & $\mathrm{C}$ & Arroyas / canyons \\
\hline Sandbur & $\mathrm{C}$ & D1sturbed ground \\
\hline Bur Brloclegrass & $c$ & D1sturbed ground \\
\hline Green Bristiegrass & c & Artoyos/d1sturbed ground \\
\hline Plains Brlstiegrass & $c$ & Arroyos/canyons/rocky slopes \\
\hline Witchgrass & $\mathrm{c}$ & Afroyos/canyons \\
\hline VIne Mesquite & $\mathrm{Hi}$ & Arroyos \\
\hline Barnyard Grass & & \\
\hline & $\mathrm{C}$ & Wet Lands/Disturbed ground \\
\hline Crabgrass & c & Arroyos/canyons/dlsturbed ground \\
\hline$-m-m-m-m$ & $-x+-\infty-\infty$ & 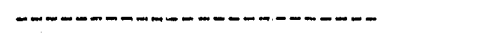 \\
\hline
\end{tabular}

Status: C - Conflrmed by collection (Martin and Wagner, 1974) H - Hypothetical 
TABLE 6.1

(CONTINUED)

\section{LIST OF PLANTS WITH A \\ MODERATE TO HIGH PROBABILITY OF OCCURRENCE ON KAFB}

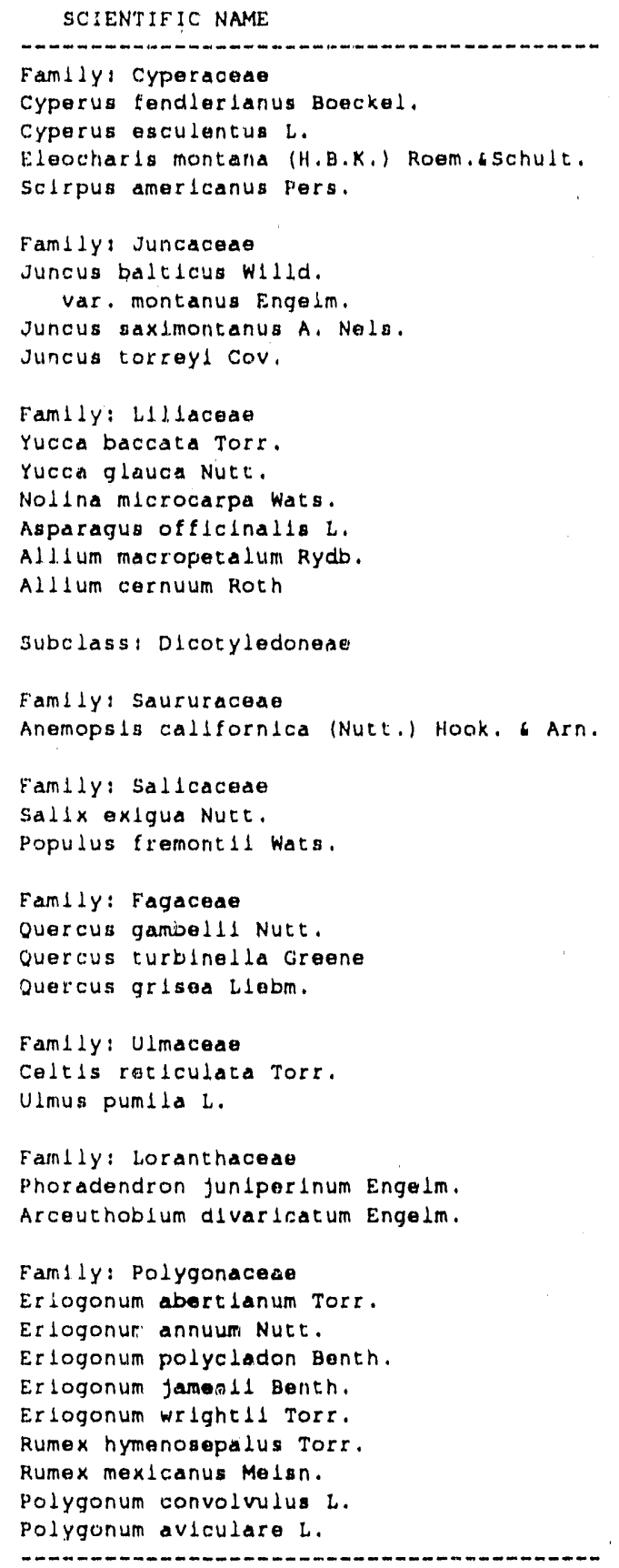

\begin{tabular}{|c|c|c|}
\hline COMMON NAME & STATUS & HABITAT \\
\hline 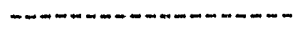 & $--\infty-\infty$ & - \\
\hline $\begin{array}{l}\text { Fendler Flatsedge } \\
\text { Yellow Nutgrasa } \\
\text { Mountaln Splkerush } \\
\text { Three-gquare }\end{array}$ & $\begin{array}{l}H \\
H \\
H \\
C\end{array}$ & $\begin{array}{l}\text { Wetlands } \\
\text { Wet lands } \\
\text { Wetlands } \\
\text { Wetlands }\end{array}$ \\
\hline HLre Ruah & & \\
\hline $\begin{array}{l}\text { Rocky Mountaln Rush } \\
\text { Torrey Rush }\end{array}$ & $\begin{array}{l}\mathrm{C} \\
\mathrm{C} \\
\mathrm{c}\end{array}$ & $\begin{array}{l}\text { Wet landa } \\
\text { Wet lands } \\
\text { Wet lands }\end{array}$ \\
\hline Banana Yucca & $\mathrm{C}$ & Rocky slopes \\
\hline Soapweed Yucca & $\mathrm{c}$ & Grasalands \\
\hline Bear Grass & $\mathrm{C}$ & Canyons/rocky s lopes \\
\hline Asparagus & $H$ & Arroyos/dlsturbed ground \\
\hline Onion & $H$ & Canyons \\
\hline Nodding onlon & $H$ & Canyons/hlgher elevation \\
\hline
\end{tabular}

$D 1 \cot s$

Yerba Mansa

C Wetlands

Coyace W1Llow

Fremont Cottonwood

H Arroyos/wot lands

Gambel Oak

Shrub Llve Oak

Gray oak

Canyons/hlgher elevac lone

Rocky slopes

Rocky sopes

Ner leaf Hackberry

Arroyo:

slberlan EIm

C Arroyos/dlsturbed ground

Mlstetoes

Junlper Mist letoo

Dwarf Mistetre

woodlands (on juntpers)

Woodlands (on plnyons)

WIld Buckwheat

Annual Wild Buckwheat

Sorral Wild Buckwheat

Antelope-sage

Wright' Wild Buckwheat

Canalgro

Dock

glack Blndweed Knotweed

Grass lands / woodlands

Grasslands/Lower slopes Arroyos/d1sturbed ground Grasslands/woodlands Grasslands/woodlands Arroyos/dlsturbed ground Arroyos/dlacurbe? ground Arroyos/d\&sturbed ground DLsturbed ground/wet lands

Status: C - Conflrmed by collection (Martin and Wagner, 1974) H - Hypothetlcal 
TABLE 6.1

(CONTINUED)

\section{LIST OF PLANTS WITH A \\ MODERATE TO HIGH PROBABILITY OF OCCURRENCE ON KAFB}

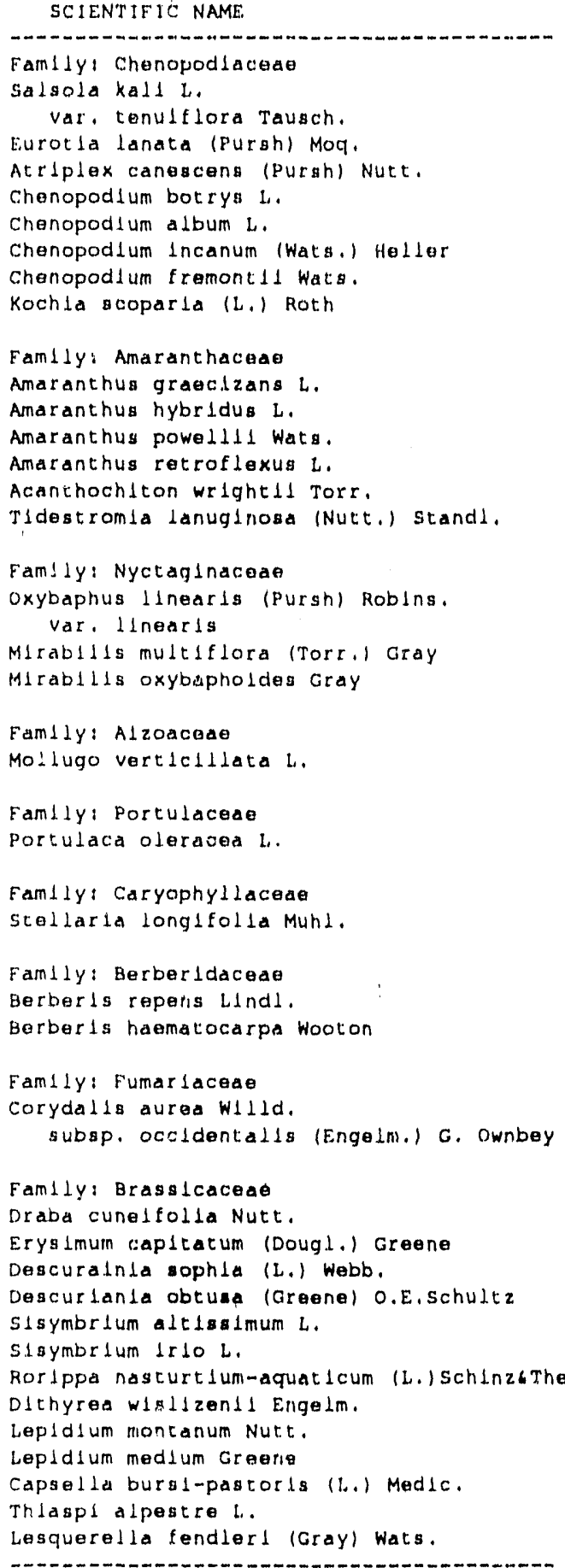
Four O'Clock
STATUS

Rusatan Thist 1

WInterfat

Four-wing saltbush

Jerualem Oak

Lamb's Quartiers

Gray Goosefoot

Fremont Coosefoot

summar Cypress

Prostrate plgweed

Plgweed

Plgweed

Green Amaranth

Four O'Clock

Carperweed

Common Purstane

Chlckweed

Creeping Mahon la Red Barberry

Golden Corydalls

Whit Low Grass
Western Wallf lower
Tansy Mustard
Tansy Mustard
rumble Mustard
London Rocket
Water Cress
Spectacle Pod
Peppergrass
Peppergrass
Shepherd's Purse
Wlid Candycut:
Bladderpod

HAB I TAT

D sturbad ground Grasulands/arroyes/rocky s lopes Grass landa / arroyes DLsturbed ground Dlaturbed ground Grasa Landa/ Lower s lopey Lower a lopes

DLaturbed ground

DL sturbed ground OLsturbed ground D s turbed ground DIsturbed ground Grasalanda/Lower glopen Grass lands / arroyos

Woodlands / arroyos

Hoodlands Woodlands/arroyog

D1sturbed ground

C DLsturbed ground

C Canyons/higher elevations

C Canyons/rocky slopes H Canyons/rocky slopes

H Canyons/rocky slopes

Arroyos/rocky alopes
Grasslands/arroyos/rocky s lopes
Dlsturbed ground
Canyons
Dlscurbed ground
Dlaturbed ground
Wetlands
Grasslands/arroyos/dlsturbed ground
Arroyos/canyons/rocky alopes
Grasulands/arroyos/disturbed ground
Grasslands/arroyos/dlsturbed ground
Canyons/hlgher elovations
Arroyos/rocky slopes

status: C - Conflrmed by sollection (Martin and Wagner, 19\%1) H - Hypothetical 
TABLE 6.1

(CONTINUED)

\section{LIST OF PLANTS WITH A \\ MODERATE TO HIGH PROBABILITY OF OCCURRENCE ON KAFB}

\author{
SCIENTIEIC NAME \\ Famlly: Capparidaceae \\ Cleome serrulata purah \\ Polanlsla trachysperma Torr.d Gray \\ Famlly: Sax ffragacea \\ Fendler ruploola oray \\ Phlladelphus mlerophyllus Gray \\ Rlbes cereum Dougl. \\ Famlly: Rosaceae \\ Prunus VIrglntana $L$, \\ var. melanociarpa (A, Nels.) Sarg. \\ Rosa Woodsll Lindl. \\ Fallugla paradoxa (D, Don.) Endl. \\ Cercocarpus montanus Raf.
}

Famlly: Fabaceae

Calllandra huml1ls Benth.

Hof fmansegg la Jamesll Torr.6 Gray

Psoralea lanceolata pursh

Psoralea tenulflora Pursh

Dalea formosa Torr.

Dalea leporina (Alt.) K.a P.

Dalea gcoparla Gray

Dalea naria Torr.

Medl cago sat lva L.

Medlcago Lupullna L.

Molllotus a bus Desr.

Melllotus offlcinalls (L.) Lam.

Lotus wright 11 (Gray) Creene

Astragalus mlasurelensls Nutt.

Aatragalus amphloxys Gray

Aatragalus humlatratus Gray

Astragalus nuttall lanus Nute.

Astragalus flexuou Dougl. ex Hook.

Astragalus crassicarpus Nut.t.

Astragalus emoryanus (Rydb.) Cory

Astragalus molldss Imus Torr.

Aatragalus lentiglnous Dougl, ex Hook.

var. dlphysus (Gray) Jones

Astragalus allochrous Gray

Petalostemum candldum (Wllld.) Mlahx.

Roblinta neomexlcana Gray

oxytropls Lambert 1 Pursh

Famlly: Geranleceao

Geranlum caespltosum James

Erodlum cltutarlum (L.) L'Her.

Famlly: oxalldaceae

oxalls stricta $L$.

Famlly: Linaceae

LInum lewis 11 Pursh

Status: C - Conflrmed by collection (Martin and Wagner, 1974) H. Hypothetical Now Mexlco Locust

\begin{tabular}{|c|c|c|}
\hline COMMON NAME & IUS & HABI'TA' \\
\hline 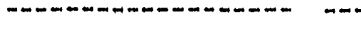 & $-\infty$ & - \\
\hline $\begin{array}{l}\text { Rocky Mountain Hee-plant } \\
\text { Clammyweed }\end{array}$ & $\begin{array}{l}H \\
\text { C }\end{array}$ & $\begin{array}{l}\text { Arroyon/rocky a lopes } \\
\text { Arroyon }\end{array}$ \\
\hline & & . \\
\hline Cllff Fendlerbush & C & Canyons/rocky s lopas \\
\hline Mock-orange & C & Canyons \\
\hline Wax Currant & $\mathrm{H}$ & Canyons/nlgher blavat Long \\
\hline
\end{tabular}

Weatern Black

Chokecherry

Woods' Rose

Apache Plume

Alder-leaf Mountaln

Mahogally

Canyon

Arroyos

Canyona/rocky slopes

\section{False Mesquite}

Rush Pea

Lemon Scurtpea

slender scurfipea

Feather Indlgobush

Pea Bush

Broom Indlgobush

Dwart Indlgobush

Alfalfa

Black Medlo

White Sweet Clover

Yellow sweet. Clover

Deer Vetch

Mlssourl M1Lkvetch

Crescent Mllkvetch

Ground Mllkvetch

Nuttall Mllkvetch

Locoweed

Ground Plum

Emory Mllkvetch

Woolly Locowend

Blue Locoweed

Hassayampa MIIkvetch White Prale le Clover

Lambert Locoweed

\section{Lower slopes}

Grass hands

Grass Lands/arroyos/woodlands

Orass Lands/arroyog/lower slopes

Orasolands/arroyos

Grasslands/arroyos

Grasalande/arroyos

Grasslands/arroyos

DLsturbed ground

Disturbed ground

Disturbed ground

DLturbed ground

Woodlands

Grasslands/arroyos/rocky s lopes Grasslands/arroyos/rocky g linpes Grasslands/arroyos/rocky s Lopes Arroyos/rocky slupeo

Grasslands/arroyon

Grass Lands/arroyos

Grasslanda/arroyos/rocky s lopes

Grass lands/arroyos/rocky s lopes

Arloyos/rocky s Lopes

Grasslands/arroyos/rocky s lopes

Grasslands/arroyos/lower s lopes Canyong

Grasslanda/arroyos/rocky s Lopes

Purpla Gerantum

Red-stem Fllaree

C Canyona/rooky s Lopes

C Grassiands/arro\%os/d1sturbed ground

Yellow Woodsorred H Canyong

Weatern Blue Flax C Grasalanda/arroyos 
TABLE 6.1

(CONTINUED)

\section{LIST OF PLANTS WITH A MODERATE TO HIGH PROBABILITY OF OCCURRENCE ON KAFB}

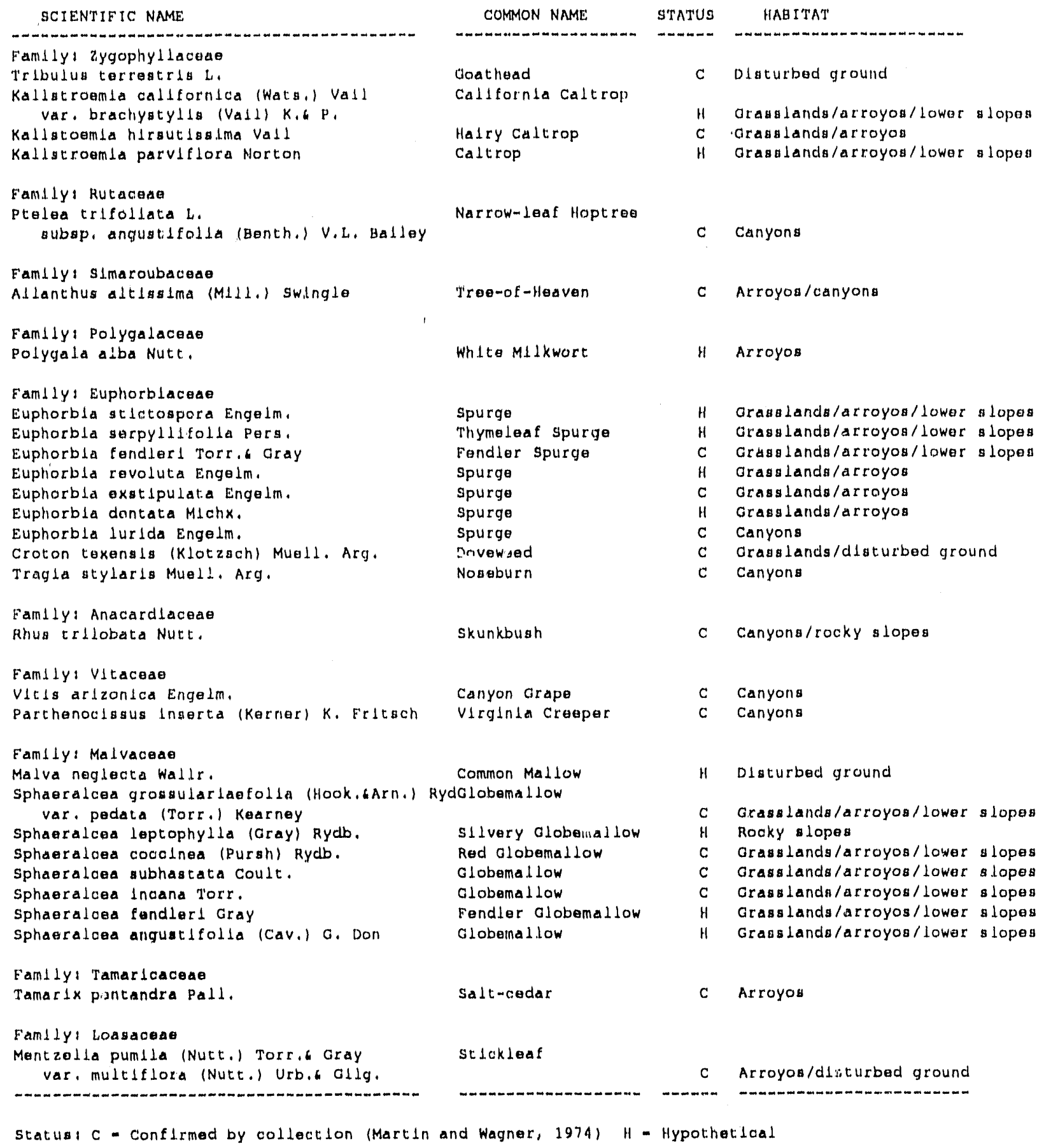


TABLE 6.1

(CONTINUED)

\section{LIST OF PLANTS WITH A \\ MODERATE TO HIGH PROBABILITY OF OCCURRENCE ON KAFB}

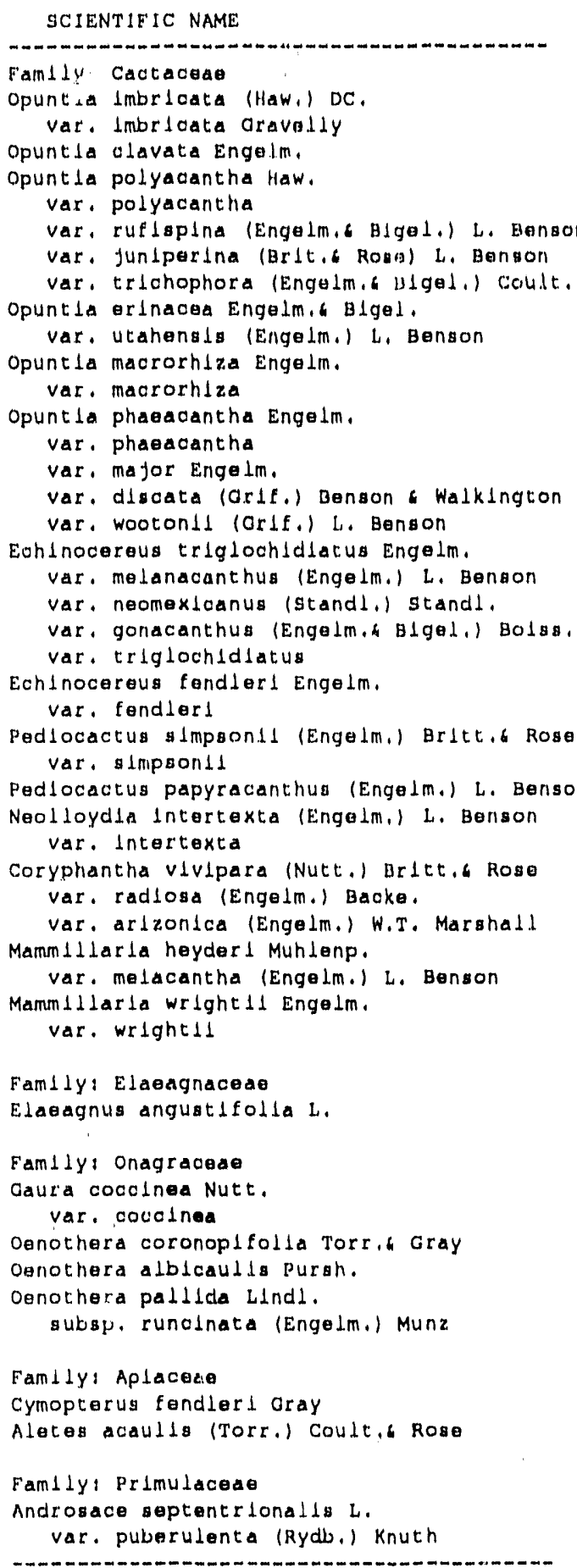

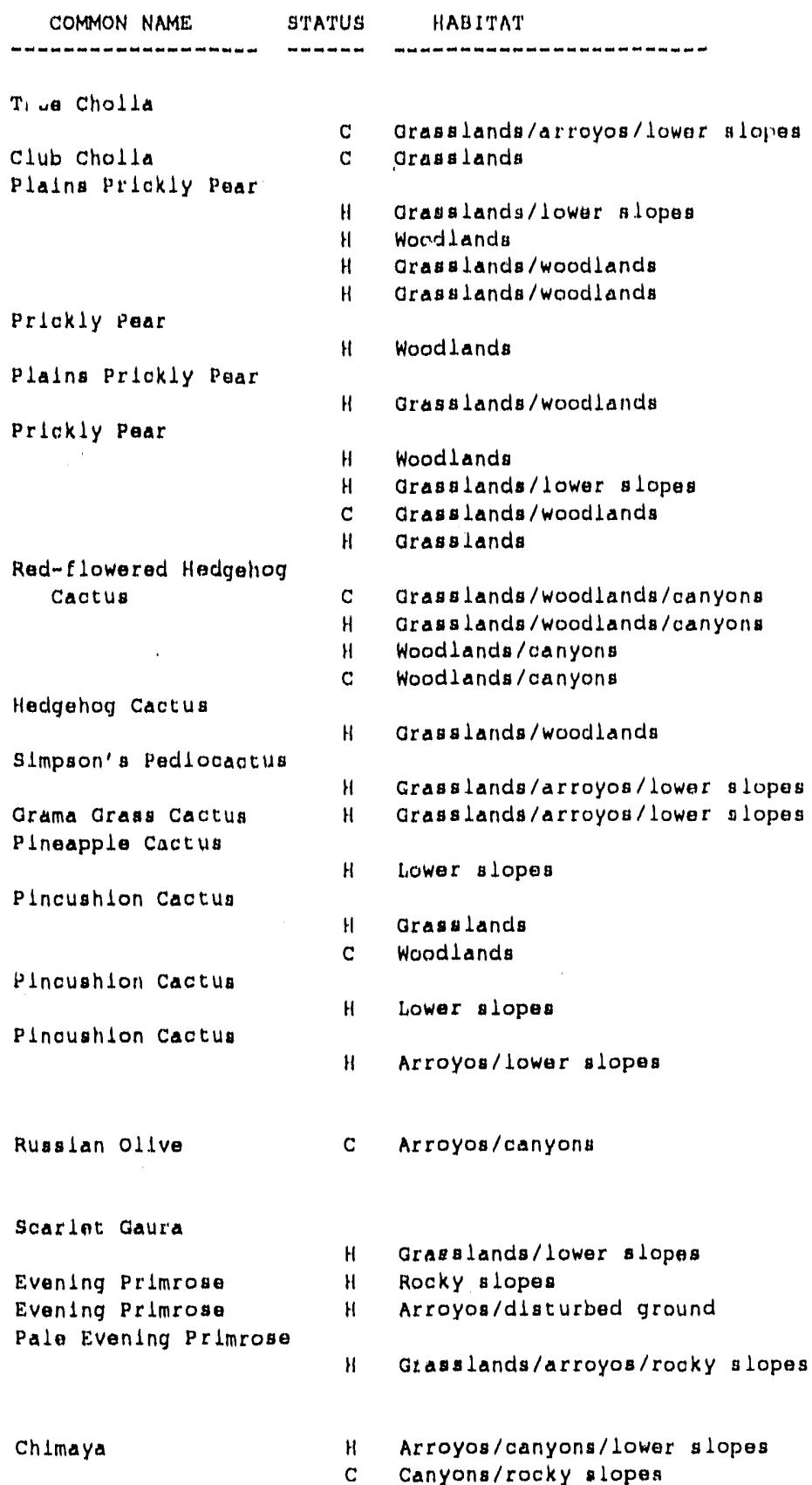

Rock Jasinlne

Status! C - Conflrmed by collection (Martin and Wagner, 1974) H - Hyporhetical 
TABLE 6.1

(CONTINUED)

\section{LIST OF PLANTS WITH A MODERATE TO HIGH PROBABILITY OF OCCURRENCE ON KAFB}

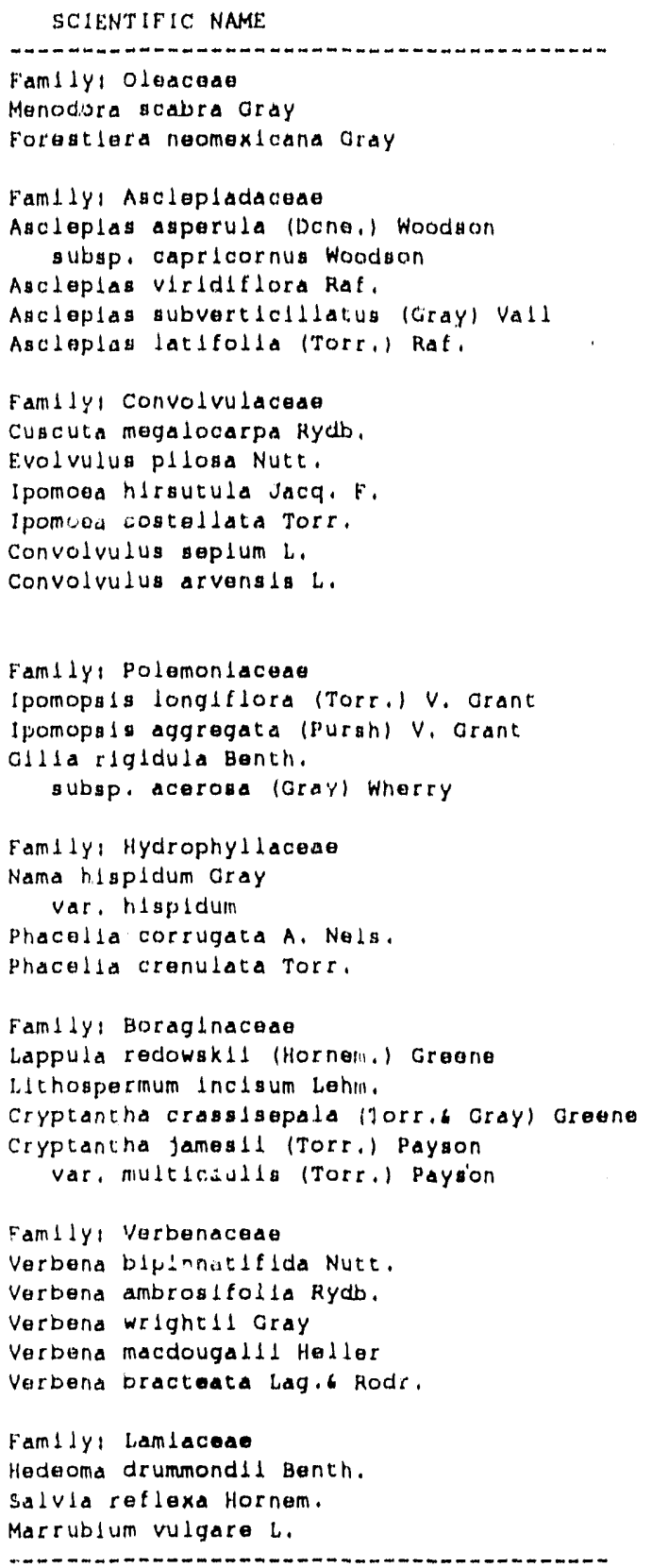

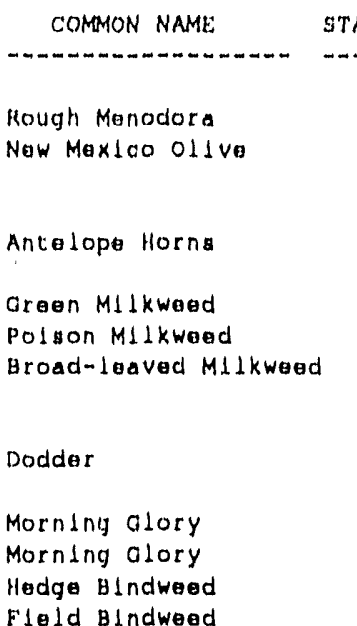

STATUS HABITAT

Gl 1 a

skyrocket

Arroyos/lower blopas Canyon:

Scorplonweed

Scorplonweed

St 1 ckwaed

Puccoon

Plalns Hlddenf lower

Dakota Vervaln

Vervaln

Vervaln

New Mexlco Vervaln

Vervaln

Falsa Pennyroyal

Rocky Mountaln Sage

Common Horehound
Grasslands/arroyos/lower slopas

Hooky lopes
Orasslandu/arroyos/dlaturbed qround araas landa/arroyos/lower a lopes

Grass Lands/woodlando Grasslands/woodlandu Dlaturbed ground Arroyos/lower slopes DL turbed ground

Dlaturbed ground

Grasa landa/azcoyos

Canyons/rooky slopos

orasslands/rocky slopes

Arroyos/canyons

orass lands/arroyos

Grasslands/rocky s lopes

Disturbed ground

Grasslands/rocky slopes

Grass lands/arroyos/rocky sopos

Grasulands/arroyos/Lower sopes

Arroyou/rocky s lojes Arroyos/lower glopes Arroyos/lower sopes Canyons/hlgher elevations

Grasslands/arroyos/disturbed ground

Status: C. Conflrmed by collection (Martin and Wagner, 1979) H - Hypothetical 
THWLIIE 6.1

(CON TINUED)

\section{LIST OF PLANTS WITH A \\ MODERATE TO HIGH PROBABILITY OF OCCURRENCE ON KAFB}

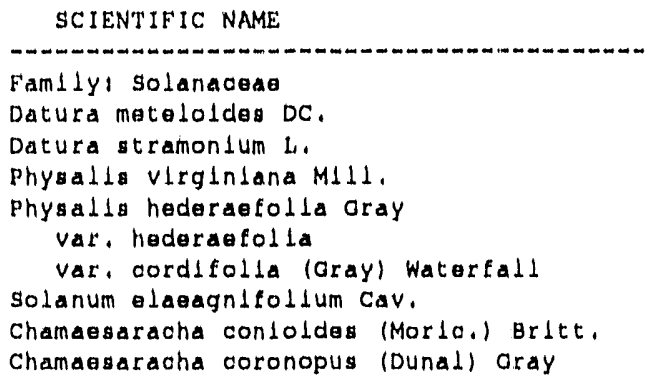

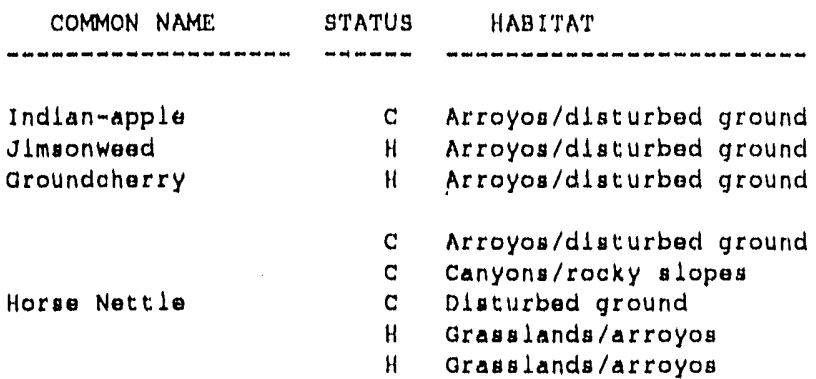

Family: Scrophular laceae

Maurandya antirrhlnlflora Humb, Bonpl.exWllld. False Snapdragon

Penstemon barbatus (Gav.) Roth

penstemon amblguus Torr.

Penstemon fameall Benth.

Mimulus glabrata H.B.K.

var, fremont1l (Benth,) Grant

Cordylanthus wright 11 gray

Cast 1lleja Integra Gray

scarlet Beardtongue

Cow Tobacco

Beardtongue

Monkeyf lower

Clubf lower

Indian Palntbrush

Fam1ly: Martynlaceae

Probosaldea parviflora (Woot,) Woot, standl. Devll's Claw

Family: Plantaglnaceae

Plantago purshll Room. Schult.

Plantago major L.

Plantago lanceolata L.

Woolly Indlan-wheat Rlppleseed Plantaln Buckhorn plantaln

Fandly: Cucurbltaceae

Cucurblta foetldisalma H.B.K.

Buffalo Gourd

Famlly: Asteraceae

stephanomerla pauciflora (Torr,) A. Nels.

Trayopogon dublous soop.

Lactuaa serrlola $L$.

Taraxacum of flcinale Wober

Sonchus asper (L.) HILl

Malacothrlx fendler 1 Gray

Perezla nana Gray

Clrs lum neomexlcanum Gray

Clrslum ochrocentrum Gray

Arct lum minus (H111) Burnh.

Xanthlum atrumarlum $L$.

var, canadenae (M111,) Torr.

Ambrosla artemilelifolla $L$.

Ambrosla pallostachya DC.

Franserla acanthlcarpa Hook. 4 Cov.

Eupatorlum herbaceum (Gray) Greene

Kuhnla chlorolepls Woot is standl.

Brlckellla brachyphylla Gray

Brlokellla callforntca (Torr.6 Gray) Gray

Brlckellla grandiflora (Hook.) Nutt.

Grindella aphanact is Rydb.

Gutlerrezla sarothrae (Pursh) Britt.q Rusby

Gutlerrezla mlerocephala (DC.) Gray

Chrysopsis villosa (Pursh) Nutt. ok DC.

Wre Lettuce

Goat's Beard

Prlakly Letcuce

Dandelion

Sow Thlstie

Desert Dandelion

Dwarf Desert-holly

Now Mexlcan Thdst 10

Santa Fe Thiatle

Burdook

Cocklebur

Common Ragweed

Western Ragweed

Burweed

Thoroughwort

False Boneset

Brloklobush

Callfornta Brlaklobush

Brloklobush

Gumweed

Snakeweed

Litt le-head snakeweed

Halry Golden Aster

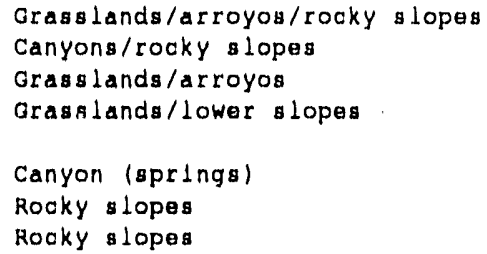

H Grasslands/arroyos

H Grasslands/rocky slopes

C Dlsturbed ground

C D1sturbed ground

C Grasslands/dlsturbed ground

Grass lands/woodlands Arroyos/disturbed ground Dlsturbed ground Dlsturbed ground D1sturbed ground Grasslands/arroyos/rocky sLopes Arroyos

Grasslands/arroyos/dtaturbed ground Grasslands/arroyos/lower slopes DLsturbed ground

D1sturbed ground/wet lands Dlsturbed ground Arroyos/canyons Grasslands/arroyos/dlsturbed ground Canyons/rocky s lopes Grasslands/rocky slopeo Arroyos/canyons/rocky slopes Canyons/roaky sopes Canyons/rocky s Lopes

D1sturhed ground

Grasslands/4, 1, surbed ground Grasslands/d1sturbed ground Grasslands/arroyos/lower slopes

status: C - Conflrmed by collection (Martin and Wagner, 1974) H . Hypotherlcal 
TABLE 6.1

(CONTINUED)

\section{LIST OF PLANTS WITH A MODERATE TO HIGH PROBABILITY OF OCCURRENCE ON KAFB}

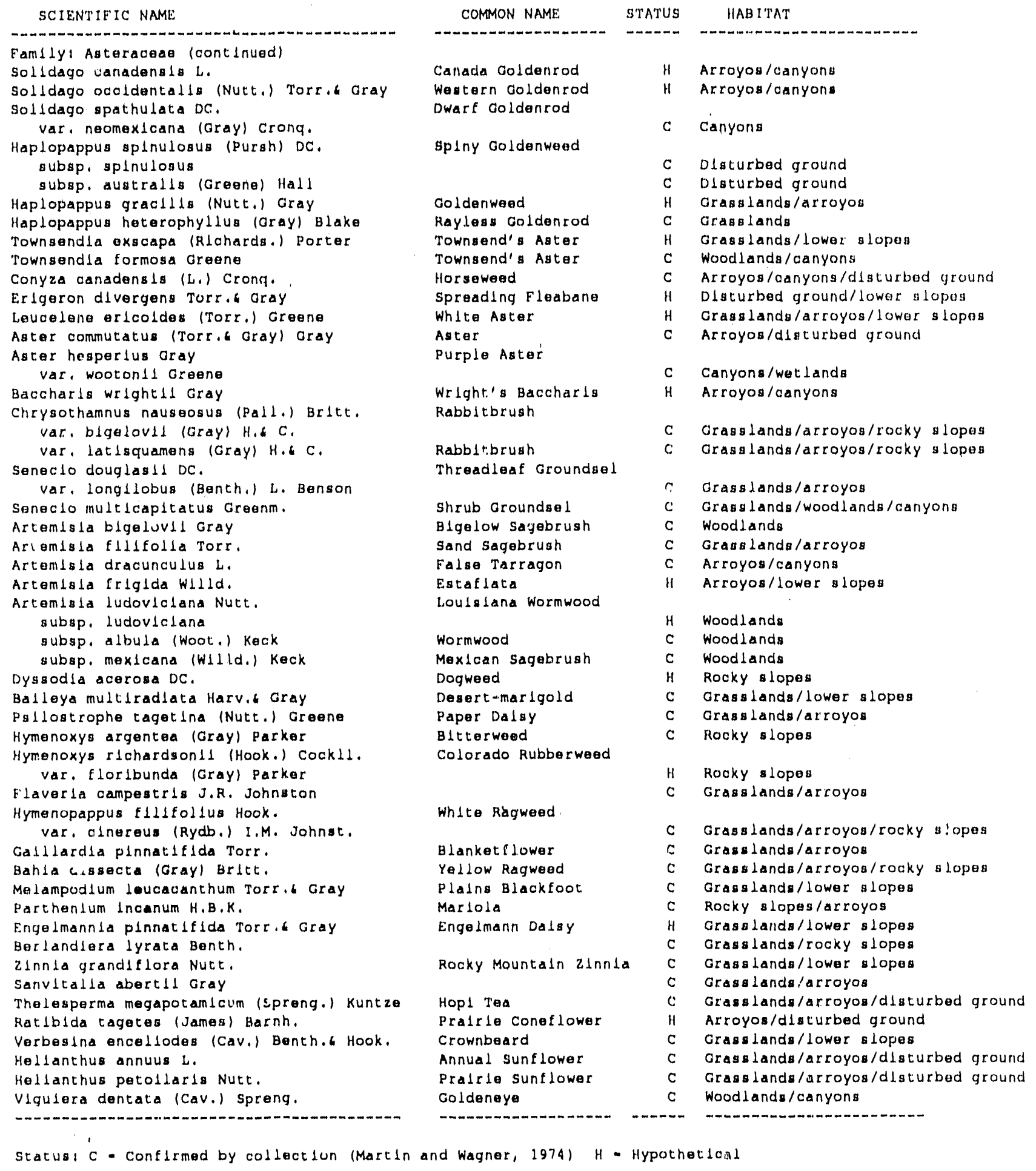




\subsection{REFERENCES}

Bailey, R. G., 1978, Description of the Ecoregions of the United States, USDA Forest Service, Intermountain Region, Ogden, Utah.

Benson, L., 1982, The Cacti of the United States and Canada. Stanford University Press, Stanford, California.

Brown, D. E., 1982, Biotic Communities of the American Southwest - United States and Mexico, Desert Plants 4(1-4): 1-324.

Department of Energy, 1988, Environmental Assessment, Strategic Defenses Facility, Sandia Natic. al Laboratories, filbuquerque, New Mexico, DOE/EA-0352, Albuquerque, New Mexico.

Findley, J. S., A. H. Harris, D. E. Wilson, and C. Jones, 1975, Mammals of New Mexico, University of New Mexico Press, Albuquerque, New Mexico.

Hacker, L. W., 1977, Soil Survey of Bernalillo County and Parts of Sandoval and Valencia Counties, New Mexico, National Cooperative Soil Survey, Washington, DC.

Hubbard, J. P., 1970, Check-list of the Birds of New Mexico, New Mexico Ornithological Society Publication No. 3., MicLeod Printing Company, Albuquerque, New Mexico.

Hubbard, J. P., 1978, Revised Check-list of the Birds of New Mexico, New Mexico Ornithological Society Publication No. 6, McLeod Printing Company, Albuquerque, New Mexico.

Martin, W. C., and C. R. Hutchins, 1980, A Flora of New Mexico, J. Cramer, Vaduz, Germany.

Martin, W. C., and W. L. Wagner, 1974, Biological Survey of Kirtland Air Force Base (East), SAND74-0393, Sandia National Laboratories, Albuquerque, New Mexico.

National Geographic Society, 1987, Field Guide to the Birds of North Arnerica, Second Edition, National Geographical Society, Washington, DC.

New Mexico Department of Game and Fish, (no date), Handbook of Species Endangered in New Mexico, Fifth Edition.

New Mexico Native Plants Protection Advisory Committee, 1984, A Handbook of Rare and Endemic Plants of New Mexico, University of New Mexico Press. Albuquerque, New Mexico.

Robbins, C. S., B. Bruun, and H. S. Zim, 1983, Birds of North America: A Guide to Field Identification, Golden Press, New York, New York.

Sandia National Laboratories, 1977, Sandia Laboratories Environmental Impact Assessment, EIAMA 77-1. 
Smith, H. M., 1978, Amphiblans of North America: A Guide to Field Identification, Golden Press, New York, New York.

Smith, H. M., and E. D. Brodie, Jr., 1982, Reptiles of North America: A Guide to Fleld Identification, Golden Press, New York, New York.

Stebbins, R. C., 1954, Amphibians and Reptiles of Western North America, McGraw-Hill Book Company, New York, New York. 

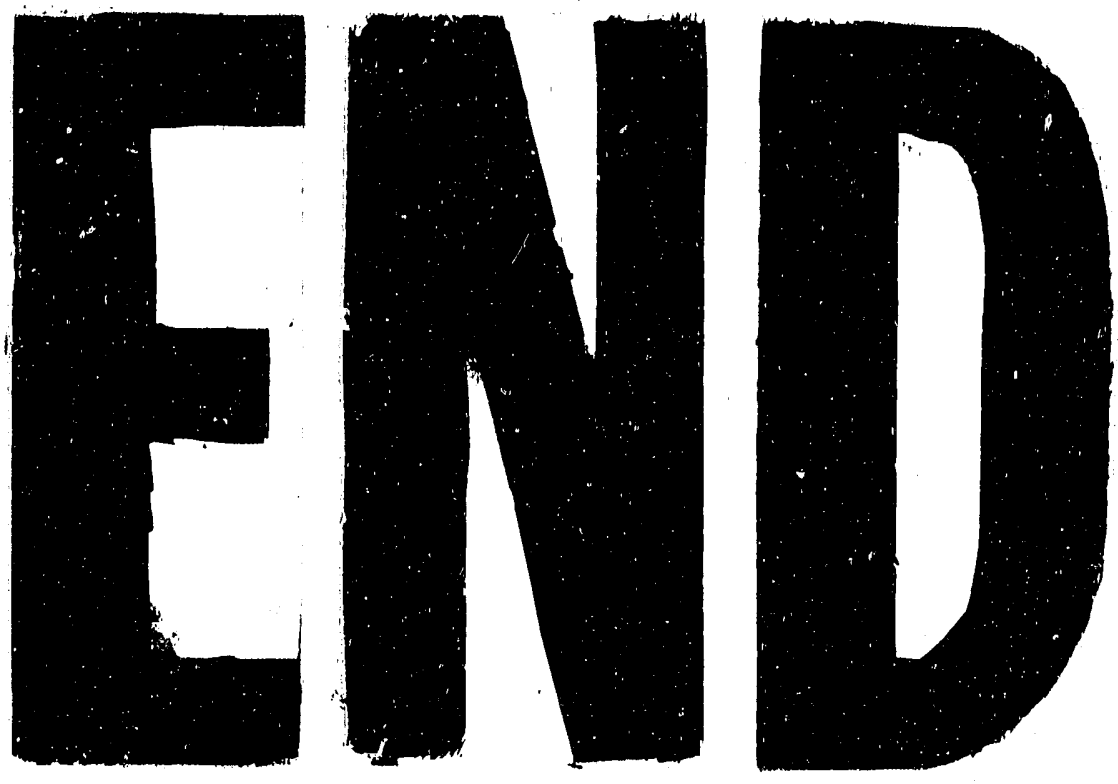

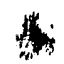
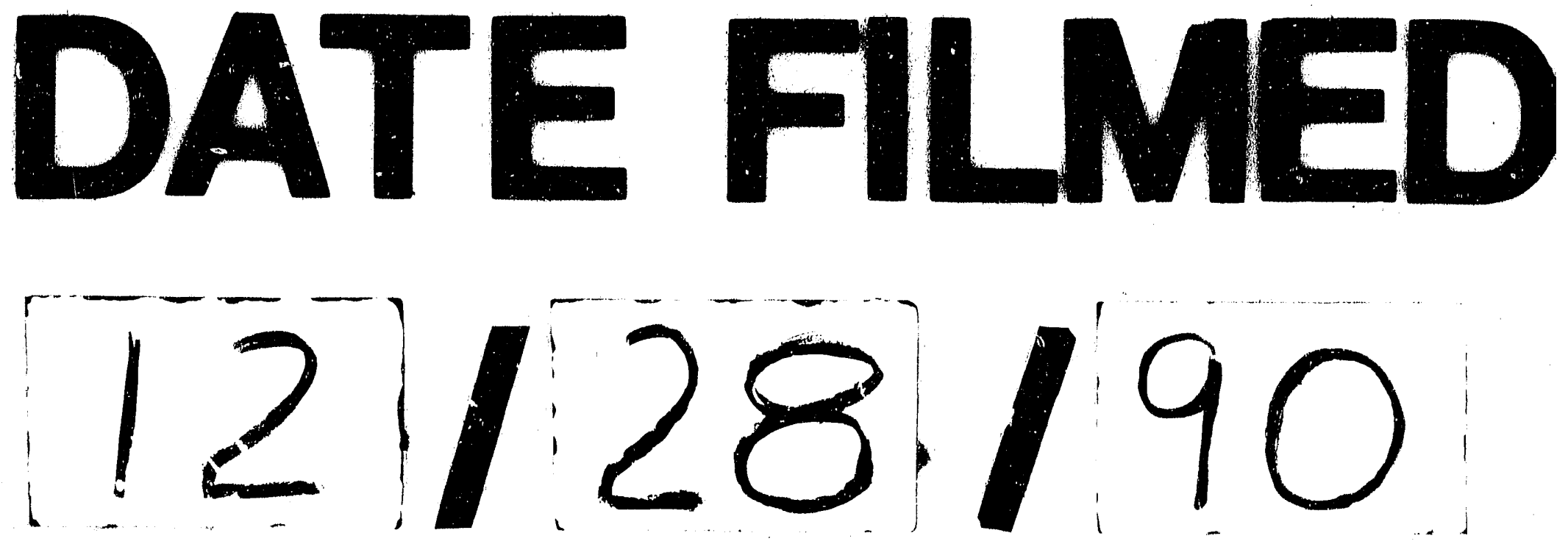
